\title{
Under the Radar:
}

\section{The Role of Fair and Equitable Benefit-sharing in Protecting and Realising Human Rights}

\author{
connected to Natural Resources
}

Elisa Morgera, Strathclyde Centre for Environmental Law and Governance, Law School, University of Strathclyde, Glasgow (elisa.morgera@strath.ac.uk)

This paper is part of the project "BENELEX: Benefit-sharing for an equitable transition to the green economy - the role of law," which is funded by the European Research Council Starting Grant (November 2013-October 2018) - Grant Number: 335592:

http://www.strath.ac.uk/research/strathclydecentreenvironmentallawgovernance/ourwork/research/benelexproject/

International environmental law and international human rights law are increasingly cross-fertilising with regard to the rights of indigenous peoples ${ }^{1}$ and local communities over natural resources traditionally used by them. ${ }^{2}$ As a result, fair and equitable benefit-sharing from the use of these natural resources is becoming increasingly relevant to prior environmental and socio-cultural assessments and consent processes. This cross-fertilisation, ${ }^{3}$ however, remains under-explored. Benefit-sharing has elicited little interest among international human rights lawyers, ${ }^{4}$ who have concentrated their efforts on the complex and still unsettled notion of free prior informed consent (FPIC) ${ }^{5}$ and difficulties in obtaining

\footnotetext{
${ }^{1}$ Indigenous peoples' right to natural resources is considered self-standing with respect to their right to land: eg, Final Report of the Special Rapporteur Erica-Irene Daes on Indigenous Peoples' Permanent Sovereignty over Natural Resources (2004) UN Doc E/CN.4/Sub.2/2004/30, para 39; and Jérémie Gilbert, 'The Right to Freely Dispose of Natural Resources: Utopia or Forgotten Right?' (2013) 31 Netherlands Quarterly of Human Rights, 314.

${ }^{2}$ Report of the Special Rapporteur on the Issue of Human Rights and the Environment John Knox: Framework Principles on Human Rights and the Environment (2017) UN Doc A/HRC/34/49, Principle 15.

${ }^{3}$ U Linderfalk, 'Cross-fertilization in International Law' (2015) 84 Nordic J Int'l L 428, at 436-438.

${ }^{4}$ It is not explicitly referred to in the UN Declaration on the Rights of Indigenous Peoples (UNDRIP: UNGA Res. 61/295, 2007). Even international human rights lawyers specifically focusing on international biodiversity law do not address benefit-sharing: eg, Ellen Desmet, Indigenous Rights Entwined with Nature Conservation (Intersentia, 2011). ${ }^{5}$ E.g. UN Expert Mechanism, Advice no. 4: Follow-up report on indigenous peoples and the right to participate in decision- making, with a focus on extractive industries, UN Doc. A/HRC/21/55, paras 38(b), 39(h) and 43 (2012); M Århén, Indigenous Peoples in the International Legal System (Oxford University Press, 2016), 217-218; and C
} 
meaningful and appropriate compensation for harm caused by extractive activities. ${ }^{6}$ In addition, benefit-sharing is often perceived as a threat to the rights of indigenous peoples. It is associated with an offer of money or other economic advantage (for instance, employment) in exchange for obtaining consent, ${ }^{7}$ which "encourages a climate of disrespect towards indigenous peoples." ${ }^{8}$ Benefit-sharing has resulted in "attempts to undermine social cohesion of affected communities" through bribes to community leaders or selective negotiations tactics. ${ }^{9}$ In particular, monetary benefit-sharing is known to "destruct the social network" of indigenous groups, ${ }^{10}$ putting in place self-defeating or paternalistic mechanisms that are not responsive to communities' specific needs. ${ }^{11}$ Regional human rights bodies have thus had occasion to point out to situations in which promised benefit-sharing were not delivered, ${ }^{12}$ or benefit-sharing arrangements were originally in place but broke down, and/or were weakened by ineffective State monitoring of outsiders' activities. ${ }^{13}$

All these benefit-sharing practices, however, can be considered "contrary to international standards" interpreted in good faith. ${ }^{14}$ This article seeks to clarify existing standards of international human rights and environmental law that, pieced together, offer an interpretation of benefit-sharing that is very far from currently wide-spread benefit-sharing practices. The proposed interpretation, instead, supports a role for benefit-sharing that is more conducive to, and intertwined with, FPIC. This

Rodríguez-Garavito, 'Ethnicity.gov: Global Governance, Indigenous Peoples, and the Right to Prior Consultation in Social Minefields' (2011) 18 Indiana Journal of Global Legal Studies 263.

${ }^{6}$ E.g. F Lenzerini (ed), Reparations for Indigenous Peoples: International and Comparative Perspectives (Oxford University Press, 2008).

${ }^{7}$ I-AmCtHR, Kichwa Indigenous Communitiy of Sarayaku v Ecuador (Merits and reparations, Judgment of 27 June 2012), para. 194.

${ }^{8}$ Ibid, paras. 193-194.

${ }^{9}$ Ibid, para. 186. J Gilbert \& C Doyle, 'A New Dawn over the Land: Shedding Light on Collective Ownership and Consent' in S Allen and A Xanthaki eds., Reflections on the UN Declaration on the Rights of Indigenous Peoples (2011) 289.

${ }^{10} \mathrm{~N}$ Gomez, 'Indigenous Peoples and Psychosocial Reparations: The Experience with Latin American Indigenous Communities' in Lenzerini (n 6) 143, 158.

${ }^{11}$ G Citrioni \& K. Quintana Osuna, 'Reparations for Indigenous Peoples in the Case of the Inter-American Court of Human Rights' in Lenzerini (n 6) 317, 340 and 324.

${ }^{12}$ African Commission on Human and Peoples' Rights (Afr. Comm.), Centre for Minority Rights Development (Kenya) and Minority Rights Group International on behalf of Endorois Welfare Council v Kenya (4 February 2010) Case 276/2003, para. 274.

${ }^{13}$ IACtHR, Case of Kaliña and Lokono Peoples $v$ Suriname, Judgment (Merits, Reparations and Costs), 25 November 2015, paras. 77-84 and 183 .

${ }^{14}$ Kichwa, para. 186. Gilbert \& Doyle (n 9) 289. 
interpretation can contribute to clarifying the limits of national sovereignty over national resources in light of international human rights of indigenous peoples ${ }^{15}$ and international obligations on environmental protection. ${ }^{16}$ In addition, the article explores avenues for further developing a mutually supportive interpretation of benefit-sharing that sheds light on the extent to which international law may make space for different worldviews of nature and development ${ }^{17}$ embodied in communities' distinctive ways of life. ${ }^{18}$ The proposed interpretation, in other words, illuminates the potential of international benefit-sharing obligations to challenge mainstream conceptions of economic development and attempts to romanticise, ossify, or bottle communities' worldviews into neo-liberal or neo-colonial agendas. ${ }^{19}$

The article will first assess the current degree of cross-fertilisation of international human rights and environmental law on benefit-sharing from the use of natural resources, focusing in particular on international biodiversity law (Section 1). It will then unveil further avenues to pursue a mutually supportive interpretation by strategically analysing the interplay of international benefit-sharing obligations ${ }^{20}$ with environmental assessment and consent (Section 1). This will serve to substantiate four inter-linked normative claims. Benefit-sharing has a substantive core linked to communities' choice and capabilities, as well as a procedural one linked to communities' agency as part of a concerted, culturally appropriate and iterative dialogue with the State. So understood, benefit-sharing expands considerably the

\footnotetext{
${ }^{15}$ F Francioni, 'Natural Resources and Human Rights' in E Morgera and K Kulovesi (eds), Research Handbook of International Law and Natural Resources 66 (Edward Elgar, 2016), in light of International Covenant on Economic, Social and Cultural Rights (ICESCR), 16 December 1966, 993 UNTS 3, art 1(2) and 2(1).

${ }^{16}$ Eg Francioni (n 15); V Barral, 'National Sovereignty over Natural Resources: Environmental Challenges and Sustainable Development', in Morgera and Kulovesi (n 15) 3; Århén (n 5), at 55; and F Lenzerini, 'Sovereignty Revisited: International Law and Parallel Sovereignty of Indigenous Peoples' (2006) 42 Tex Int'l LJ 155.

${ }^{17}$ A Barros, 'The Fetish Mechanism: A Post-Dogmatic Case Study of the Atacama Desert Peoples and the Extractive Industries' in C Lennox and D Short (eds), Handbook of Indigenous Peoples' Rights (Routldge, 2016) 223, $231-232$.

${ }^{18}$ G Pentassuglia, 'Towards a Jurisprudential Articulation of Indigenous Land Rights' (2011) 22 EJIL 165, 176; D McGregor, 'Living Well with the Earth: Indigenous Rights and the Environment' in Lennox and Short (n 17) 167, 175; Desmet (n 4), 58 and 175; and Francioni (n 15).

${ }^{19}$ E Reimerson, 'Between Nature and Culture: Exploring Space for Indigenous Agency in the Convention on Biological Diversity' (2013) 22 Envtl. Pol. 992; Y Uggla, 'What is This Thing Called 'Natural'? The Nature-culture Divide in Climate Change and Biodiversity Policy' (2009) 17 J. Pol. Ecology 79.

${ }^{20}$ It has been argued elsewhere that fair and equitable benefit-sharing is a multi-dimensional international law concept, encompassing an inter-State as well as an intra-State dimension: E Morgera, 'The Need for an International Legal Concept of Fair and Equitable Benefit-sharing' (2016) 27 EJIL 353. The present article focuses specifically on the intraState dimension of benefit-sharing.
} 
scope and approach of environmental assessments and consultation practices. It allows to move beyond a defensive approach that conceptualises benefit-sharing as a mere procedural "safeguard" 21 towards a potentially transformative collaboration in light of indigenous understandings. Benefit-sharing should then be distinguished from compensation, with which it is often conflated, ${ }^{22}$ as it does not depend upon a violation of a right. Finally, the proposed interpretation of benefit-sharing has implications for understanding the status of fair and equitable benefit-sharing in international law (Section 3), as well as for businesses' due diligence to respect the human rights of indigenous peoples and local communities (Section 4).

\section{The extent of cross-fertilisation}

This section sheds light on the current degree of cross-fertilisation between international human rights and environmental law. It also calls attention to the respective blindspots of these two areas of law, with a view to underscoring the need for furthering mutual supportiveness.

International human rights law has placed benefit-sharing to the service of a number of specific human rights, thereby clarifying the minimum content of the international obligation of benefit-sharing. References to benefit-sharing have, however, relied on limited legal bases in international human rights law, which explains increasingly reliance by international human rights bodies on "universal standards" 23 developed under the Convention on Biological Diversity (CBD). Consensus guidance adopted under the CBD, in turn, has clarified how to concretely apply benefit-sharing in the specialised context of natural resource and protected areas governance. CBD consensus guidance thus provides a

\footnotetext{
${ }^{21}$ UN Special Rapporteur Anaya, Progress report on extractive industries, UN Doc. A/HRC/21/47, paras 52 and 62 (2012).

${ }^{22}$ Making reference more consistently to "ensur[ing] reasonable benefit or compensation for indigenous peoples impacted by natural resource exploitation”: OHCHR, Mapping Human Rights Obligations Relating to the Enjoyment of a Safe, Clean, Healthy and Sustainable Environment: Individual Report on the International Convention on the Elimination of Racial Discrimination (2013), at 16-18 (emphasis added).

${ }^{23}$ A Fodella, 'Indigenous Peoples, the Environment, and International Jurisprudence' in N Boschiero, et al eds. International Courts and the Development of International Law: Essays in Honour of Tullio Treves (Springer, 2013), 360, develops this argument about international human rights law, not international biodiversity law.
} 
pragmatic complement to the evolutionary interpretation of the human rights obligation of benefitsharing. CBD instruments, however, have not engaged explicitly with human rights language, avoiding questions related to minimum standards of protection and justiciability.

\subsection{The perspective of international human rights law}

On the human rights side, the only treaty-based reference to benefit-sharing in relation to indigenous and tribal peoples can be found in ILO Convention No 169. The right to participate in the use, management and conservation of natural resources "pertaining to [indigenous and tribal peoples'] lands" encompasses a right to participate in the benefits arising from these activities "wherever possible," even when the State retains the ownership or other rights to these resources. ${ }^{24}$ This provision was considered one of the "most polemic" in the negotiating history of the ILO Convention and "entirely new. ${ }^{25}$ Likely for these reasons, the Convention does not determine the exact scope of the benefitsharing obligation, allowing for considerable scope for discretion in its implementation. Such leeway serves to accommodate variations among domestic legal systems' approaches to the recognition of indigenous and tribal peoples, but also the necessary flexibility for case-by-case implementation in the light of the specific circumstances of indigenous peoples. ${ }^{26}$ At the very least, the benefit-sharing provision arguably obliges State Parties to demonstrate when and why it is not possible to share benefits. $^{27}$

\footnotetext{
${ }^{24}$ International Labour Organization's (ILO) Convention no. 169 Concerning Indigenous and Tribal Peoples in Independent Countries 1989, 28 ILM 1382, art 15.

${ }^{25}$ L Swepston, 'New Step in the International Law on Indigenous and Tribal Peoples: ILO Convention No. 169 of 1989' (1990) 15 Okla. City U. L. Rev. 677, 703. The only other reference to benefit-sharing in human rights law is in the Universal Declaration on Human Rights: Blogpost by Mikel Mancisidor, Is There Such a Thing as a Human Right to Science in International Law? (April 2015) at http://www.esil-sedi.eu/node/896. While the ILO Convention uses the verb to "participate" in benefits, its interpretative materials refer to benefit-sharing: e.g., Observation of the Committee of Experts on the Application of Experts, adopted 2009, published 99th ILC session (2010), para. 11.

${ }^{26}$ ILO, Monitoring Indigenous and Tribal Peoples' Rights through ILO Conventions: A Compilation of ILO Supervisory Bodies' Comments 2009-2010, Observation (Norway), Canadian Environmental Assessment Research Council 2009/80th session (2009), 95; ILO, Indigenous and Tribal Peoples' Rights in Practice: A Guide to ILO Convention No 169 (2009), 107-108; and L Sargent, 'The Indigenous Peoples of Bolivia's Amazon Basin Region and ILO Convention No. 169: Real Rights or Rhetoric?' (1998) 29 U. Miami Inter-Am. L Rev 451, 510.

${ }^{27}$ Swepston (n 25) 704-706.
} 
In practice, the ILO Convention provision on benefit-sharing has led to profit-sharing from extractive activities, ${ }^{28}$ which is a common feature of international human rights law and represents one of its blindspots. As former Special Rapporteur Anaya warned, "benefit sharing must go beyond restrictive approaches based solely on financial payments which, depending on the specific circumstances, may not be adequate for the communities receiving them." ${ }^{29}$ In particular, empirical evidence suggests that non-monetary benefits may exceed the importance of monetary benefits for communities' wellbeing. ${ }^{30}$ Furthermore, monetary benefits have had documented negative (including divisive) effects on communities, and have been linked to the exercise of undue influence and bribery. Benefit-sharing thus needs to be understood in its interaction with other obligations under ILO Convention 169: the assessments of social, spiritual, cultural and environmental impacts of planned development activities, ${ }^{31}$ good-faith consultation through indigenous peoples' representative institutions, ${ }^{32}$ and cooperation with indigenous peoples in adopting environmental protection measures in their territories. ${ }^{33}$ It is the combination of these obligations that may allow to take into account indigenous peoples' holistic worldviews of their 'territories, which cover the total environment of the areas which the peoples concerned occupy or otherwise use." ${ }^{, 34}$

The benefit-sharing provision of ILO Convention No 169 has proven influential, even when not formally applicable, in the Saramaka case ${ }^{35}$ and the subsequent "solid line of case law" 36 of the

\footnotetext{
${ }^{28}$ ILO, Report of the Committee Set Up to Examine the Representation Alleging Non-Observance by Ecuador of ILO Convention No. 169, Doc. GB.282/14/4 (2001), para. 44(3); Report of the Committee set up to Examine the Representation alleging non-observance by Ecuador of ILO Convention No. 169, ILO Doc. GB.282/14/4, para. 44(3) (2001).

${ }^{29}$ Special Rapporteur Anaya, Report on the situation of human rights and fundamental freedoms of indigenous people, (2010) UN Doc. A/HRC/15/37, para. 80.

${ }^{30} \mathrm{R}$ Wynberg \& M Hauck, 'People, Power and the Coast: Towards an Integrated, Just and Holistic Approach' in R Wynberg \& M Hauck (eds) Sharing Benefits from the Coast: Rights, Resources and Livelihoods (UCT Press, 2014) 143,158 .

${ }^{31}$ ILO Convention, art 7(3).

${ }^{32}$ Combined reading with ILO Convention, arts 5-6.

${ }^{33}$ ILO Convention, art 7(4).

${ }^{34}$ ILO Convention, art 15(2); Swepston (n 25), 698; and Desmet (n 4), 88.

${ }^{35}$ IACtHR, Case of the Saramaka People v. Suriname, Judgment (Preliminary Objections, Merits, Reparations and Costs), 28 November 2007.

${ }^{36}$ For a recount of this line of case law, see Kaliña and Lokono Joint Concurring Opinion of Humberto Antonio Sierra Porto and Eduardo Ferrer Mac-Gregor Poisot, paras. 4-9.
} 
Inter-American Court of Human Rights. Benefit-sharing has been considered a safeguard for indigenous and tribal peoples' right to freely dispose of their natural resources as a means to determine their own social, cultural and economic development, and enjoy their way of life. ${ }^{37}$ As is well known, the Saramaka line of reasoning has had visible impact on the African framework on human rights, ${ }^{38}$ as well as on global human rights processes. ${ }^{39}$ As a result of these jurisprudential developments, benefit-sharing has been repeatedly identified as one of three safeguards, together with prior impact assessment and FPIC, in the case of proposed extractives in or near indigenous lands. Equally, benefit-sharing has been considered as a safeguard in the case of proposed conservation activities, such as the establishment of protected areas, in indigenous lands. In this case, benefitsharing operates together with FPIC and indigenous peoples' effective participation in management and monitoring of traditional territories, including continued access and use that are compatible with environmental protection. ${ }^{40}$ These obligations are triggered when proposed activities may threaten indigenous peoples' and local communities' physical or cultural survival. ${ }^{41}$ The Inter-American Court identified two situations in which such survival is at stake: either proposed development projects or

\footnotetext{
${ }^{37}$ Saramaka (Merits), paras. 93-95 on the basis also of Inter-American Convention, art 29(b). Reiterated in Kaliña and Lokono, para. 124; e.g. Århén (n 5), 93.

${ }^{38} \mathrm{G}$ Pentassuglia, 'Indigenous Groups and the Developing Jurisprudence of the African Commission on Human and Peoples' Rights: Some Reflections' (2010) 3 UCL Hum. Rts. Rev. 150, 158 with respect to the Endorois case. See also African Court on Human and Peoples' Rights, African Commission of Human and Peoples' Rights $v$ The Republic of Kenya (26 May 2017) App. No 006/2012, para 191.

${ }^{39}$ Independent Expert on Environment and Human Rights, John Knox, Preliminary Report on the Issue of Human Rights Obligations Relating to the Enjoyment of a Safe, Clean, Healthy and Sustainable Environment, UN Doc. A/HRC/22/43, para. 41 (2012) and Mapping Report, UN Doc. A/HRC/25/53, para. 78 (2013); UN Special Rapporteur on the Right to Food, Oliver de Schutter, Large-scale land acquisitions and leases: A set of minimum principles and measures to address the human rights challenge, UN Doc. A/HRC/13/33/Add.2, paras. 30-33 (2009); Special Rapporteur Anaya, A/HRC/21/47 (n 21), paras. 52 and 62; UN Expert Mechanism, Indigenous Peoples and Human Rights, Setting a Framework for Consultation, Benefit-Sharing and Dispute Resolution, UN Doc.

A/HRC/EMRIP/2009/5 (2008); and UN Expert Mechanism, Follow-up report on indigenous peoples and the right to participate in decision-making, with a focus on extractive industries, UN Doc. A/HRC/EMRIP/2012/2, para. 40 (2012). But it remains unclear whether the Human Rights Committee (HRC) relies upon the same notion of benefit-sharing found in Saramaka: note the lack of reference to benefit-sharing in Office of the UN High Commissioner for Human Rights (OHCHR), Mapping Human Rights Obligations Relating to the Enjoyment of a Safe, Clean, Healthy and Sustainable Environment: Individual Report on the International Covenant on Civil and Political Rights (2013). ${ }^{40}$ See Endorois and Kaliña and Lokono; and Special Rapporteur Anaya, Cases examined by the Special Rapporteur (June 2009 - July 2010), UN Doc. A/HRC/15/37/Add.1, paras. 257-267 (2010); and Report of the Special Rapporteur Anaya to the General Assembly (2016) UN Doc A/71/229, which does not refer to benefit-sharing as such, but to partnership building (paras 74 and 80).

${ }^{41}$ Saramaka (Merits), paras. 122-123; P Thornberry, Indigenous Peoples and Human Rights 352 (Manchester University Press, 2002), 282.
} 
conservation initiatives concern natural resources that are traditionally used by indigenous and tribal peoples; or the extraction of natural resources (notably minerals) that are not traditionally used by indigenous peoples is likely to affect other natural resources that are. ${ }^{42}$ This is in line with ILO monitoring bodies' view that not only projects implemented in traditional lands, but also those having an impact on communities' life require a heightened level of protection. ${ }^{43}$ It has been noted, however, that the African Commission's approach is more progressive than the Inter-American Court's one, as the former underscored the need to protect natural resources found on or under indigenous land, rather than only those resources the extraction of which may have a negative impact on the group indirectly. $^{44}$

At the time of the Saramaka case, the Inter-American Court argued that benefit-sharing was already recognised in "the text of several international instruments." 45 But actually there were only few "tentative" 46 legal bases on benefit-sharing in international human rights law on which it could rely upon. The UN Declaration on the Rights of Indigenous Peoples (UNDRIP), for instance, does not include an explicit reference to benefit-sharing. This has been considered implicit in its provisions on the right to natural resources over time (after the Saramaka decision). ${ }^{47}$ The Committee on the Elimination of Racial Discrimination (CERD) $)^{48}$ and the UN Special Rapporteur on Indigenous

\footnotetext{
${ }^{42}$ Saramaka (Merits), paras. 155-158.

${ }^{43}$ S Errico, 'The Controversial Issue of Natural Resources: Balancing States' Sovereignty with Indigenous Peoples' Rights' in Allen and Xanthaki (n 9), 348.

${ }^{44}$ Pentassuglia (n 38), 160.

45 Saramaka (Merits), para. 130 and fn 128; and para. 138 and fn 137.

${ }^{46}$ Pentassuglia (n 38), 169.

${ }^{47}$ UNDRIP, art 31; Special Rapporteur Anaya, A/HRC/15/37 (n 29), paras. 67 and 76-78 (2010); UNPFII, Review of World Bank operational policies, UN Doc. E/C.19/2013/15, para. 27 (2013); OHCHR, Mapping Human Rights Obligations Relating to the Enjoyment of a Safe, Clean, Healthy and Sustainable Environment: Individual Report on the Rights of Indigenous Peoples (2013), 45-46.

${ }^{48}$ International Convention on the Elimination of All Forms of Racial Discrimination, 7 March 1966, 660 UNTS 195; Fn 138, para. 140 referring to CERD, Consideration of Reports submitted by State Parties under Article 9 of the Convention, Concluding Observations on Ecuador, UN Doc. CERD/C/62/CO/2, para. 16 (2003). Note that a benefitsharing requirement does not feature in the CERD General Recommendation n. 23 on Indigenous Peoples UN Doc. A/52/18, annex V (1997), but references to profit-sharing from natural resource use were made by CERD:

Consideration of Reports, Comments and Information Submitted by States Parties: Bolivia, UN Doc. A/66/18, para. 43(7)(f) (2012); and Consideration of Reports, Comments and Information Submitted by States Parties: Bolivia, UN Doc. A/56/18, para. 335 (2001).
} 
Peoples $^{49}$ sporadically mentioned benefit-sharing before, but have equally focused more systematically on benefit-sharing post Saramaka.

The limited legal bases on benefit-sharing under international human rights law may explain why the Inter-American Court, ${ }^{50} \mathrm{CERD}^{51}$ and other global human rights processes ${ }^{52}$ have made increasingly reference to other standards developed under the CBD. This is notably case of the CBD Akwé: Kon Guidelines on socio-cultural and environmental impact assessments, which include reference to benefit-sharing. ${ }^{53}$ Similar is the case of benefit-sharing guidance included in CBD decisions on protected areas, ${ }^{54}$ that have been identified as relevant by human rights bodies to prevent negative impacts from conservation activities on indigenous and tribal peoples' territories. ${ }^{55}$ But it has only been in the 2015 Kaliña and Lokono decision that the Inter-American Court has been particularly explicit about the need for, and merits of, mutual supportiveness with consensus guidance adopted under the CBD. ${ }^{56}$ On that occasion, the Court underscored States' obligations to protect, in a manner compatible with their international environmental obligations, indigenous peoples' rights to a dignified life and to cultural identity connected with natural resources on their traditional

\footnotetext{
${ }^{49}$ Referring to "mutually acceptable benefit-sharing" as part of FPIC: Report of the Special Rapporteur on the situation of human rights and fundamental freedoms of indigenous peoples, Rodolfo Stavenhagen, UN Doc. E/CN.4/2003/90, para. 66 (2003); which was reiterated in his Progress report on preparatory work for the study regarding best practices carried out to implement the recommendations contained in the annual reports of the Special Rapporteur, UN Doc. E/CN.4/2006/78/Add.4, para. 11.

${ }^{50}$ Inter-American Court of Human Rights (IACtHR), Case of the Saramaka People v. Suriname, Judgment (Interpretation of the Judgment on Preliminary Objections, Merits, Reparations and Costs), 12 August 2008, para. 41 and fn 23.

${ }^{51}$ Which appears confirmed in CERD, Concluding observations on the combined thirteenth to fifteenth periodic reports of Suriname, (2015) UN Doc. CERD/C/SUR/CO/13-15, para. 26.

${ }^{52} \mathrm{CBD}$ art $8(\mathrm{j})$ was referred to by UNPFII, Review of Developments pertaining to the Promotion and Protection of Human Rights and Fundamental Freedoms of Indigenous Peoples, UN Doc. E/CN.4/Sub.2/AC.4/2001/2, para. 15 (2001). The Akwé: Kon Guidelines (CBD Decision VII/16C (2004), Annex) were referred to as a pre-condition for benefit-sharing by CERD (n 51); Special Rapporteur Anaya, A/HRC/15/37 (n 29), para. 73, and by the Expert Mechanism, Progress report on the study on indigenous peoples and the right to participate in decision-making, (2010) UN Doc. A/HRC/15/35, para. 37. The CBD work programme on protected areas (CBD Decision VII/28 (2004), Annex) was referred to by the Expert Mechanism, UN Doc. A/HRC/15/35, para. 37 (2010).

${ }^{53}$ Akwé: Kon Guidelines (n 52), paras. 46 and 56.

${ }^{54}$ Work programme on protected areas (n 52), paras. 2(1) and 2(1)(4) (while the latter refers to both benefit- and costsharing, the focus on benefit-sharing is clarified in CBD Decision IX/18 (2008), preamble para. 5).

${ }^{55}$ See generally Reimerson (n 19).

${ }^{56} \mathrm{CBD}$ arts 8(j), 10 and 14: Kaliña and Lokono, paras. 173-174, 177-178, 181 and $214 \mathrm{fn}$ 247, making reference to the Addis Ababa Principles and Guidelines for the Sustainable Use of Biodiversity, CBD Decision VII/12 (2004), Annex II and the CBD work programme on protected areas (n 52).
} 
territories. $^{57}$

Admittedly, universal and regional human rights jurisprudence has not developed a consistent legal argumentation on benefit-sharing, and interpretative guidance has gradually been formulated across various decisions and other international materials. The argument put forward here is that on the whole, international human rights has identified in significant detail the minimum level of protection afforded by benefit-sharing, although guidance on how to implement benefit-sharing obligations remains limited and quite abstract. The latter is another important blindspot in international human rights law.

International human rights processes have indicated that prior environmental and sociocultural assessments (which include consideration of benefit-sharing options) should be prepared by an independent, technically qualified entity with the "active participation of indigenous communities concerned. ${ }^{, 58}$ In addition, these assessments must respect indigenous traditions and cultures. ${ }^{59}$ This is a key clarification to ensure that communities influence the terms of the debate, rather than participate in a process already framed around a predetermined set of development options. Thus conceived, these assessments are expected to contribute to realise indigenous peoples' right to participate in public affairs. ${ }^{60}$ In addition, human rights bodies have recommended establishing processes for recording indigenous communities' views also when they are unable to attend public meetings because of remoteness or poor health, as well as in other forms than written ones. ${ }^{61}$ Governments are further expected to provide adequate human, financial, technical and legal resources to support indigenous expertise, proportionally to the scale of the proposed development. ${ }^{62}$ In addition, the Guidelines recommend involving indigenous communities in the financial auditing processes of the development to ensure that the resources invested are used effectively. ${ }^{63}$

\footnotetext{
${ }^{57}$ Kaliña and Lokono, paras. 181 and 193.

${ }^{58}$ Kichwa, para. 300; Kaliña and Lokono, para. 214; CERD (n 51), para. 26.

${ }^{59}$ Saramaka (Interpretation), para. 41; Kichwa, para. 206; Kaliña and Lokono, para. 215; also citing Principle 10 of the Rio Declaration on Environment and Development (1992) 'UN Doc A/CONF.151/26 vol 1, Annex 1.

${ }^{60}$ Kaliña and Lokono, paras. 197 and 202-203.

${ }^{61} \mathrm{Ibid}$, para. 17.

${ }^{62} \mathrm{Ibid}$, paras. 18 and $64-66$ and 70 .

${ }^{63}$ Ibid, para. 46.
} 
Procedural safeguards have thus featured prominently in human rights case law. International human rights bodies have also underscored the need for benefit-sharing agreements to be recorded formally, ${ }^{64}$ in a legally binding agreement embodying the conditions for granting FPIC in light of communities' worldviews, and the safeguards against the disrespect of such consent after it is granted. ${ }^{65}$ Benefit-sharing agreements are further expected to undergo third-party verification, ${ }^{66}$ and be made subject to an ongoing review of their functioning jointly with indigenous peoples. ${ }^{67}$

Regional human rights jurisprudence has also elaborated on the need for judicial protection. The Inter-American Court emphasised States' obligation to deploy effective means to safeguard rights through judicial organs, and provide the means to execute relevant decisions of public authorities and judgments. ${ }^{68}$ Remedies offered by the State should provide a "real possibility" for indigenous and tribal peoples to defend their rights and exercise effective control over their territory, ${ }^{69}$ including through the recognition of legal standing to file administrative, judicial or other type of action collectively, through their representatives, or individually, taking into account their customs and cultural characteristics. Reference is also made to guarantees of access to justice that are accessible, simple and within reasonable timeframes; access to technical and legal assistance, ensuring the community members can be understood in and can understand legal proceedings; and facilitation of physical access to administrative and judicial institutions in light of geographical distance, elevated costs or other challenges. ${ }^{70}$ Such measures are also expected to respect internal mechanisms for deciding disputes on indigenous issues, which are in harmony with human rights. ${ }^{71}$

Finally, justiciability rests on the obligation for States to enshrine international benefit-sharing obligations in national law to clarify that benefit-sharing is an entitlement, not a mere privilege. This

\footnotetext{
${ }^{64}$ Ibid, para. 193.

${ }^{65}$ UN Expert Mechanism (n 5), para. 43; Special Rapporteur Anaya, A/HRC/15/37 (n 29), para 46.

${ }^{66}$ UNPFII (n 47), para. 29.

${ }^{67}$ ILO, Observation on Norway (n 26).

${ }^{68}$ Kaliña and Lokono, paras. 239-240.

${ }^{69}$ Ibid.

${ }^{70}$ Ibid, para. 251(3).

${ }^{71} \mathrm{Ibid}$, para. 251(5).
} 
implies that benefit-sharing obligations are irrevocable and part of a legally backed opportunity to effectively control natural resources without outside interference. ${ }^{72}$ Appropriate national legislation on benefit-sharing has been considered a guarantee of non-repetition by the Inter-American Court. ${ }^{73}$ Integrating these procedural guarantees as essential conditions for benefit-sharing under the CBD would respond to some of the main shortcomings arising from the lack of explicit discussion of human rights standards under international biodiversity law, which will be discussed in the next section.

\subsection{The perspective of international environmental law}

To an environmental lawyer, the growing references in international human rights materials to the CBD may appear surprising. The CBD and its decisions do not include human rights terminology. ${ }^{74}$ Rather, CBD negotiations provide ample evidence of States' attempts to firewall this regime from international human rights law, resulting in convoluted and heavily qualified language that may have human rights implications. ${ }^{75}$ Clearly certain States among the 196 CBD Parties do not wish to import through the backdoor of the CBD international standards on indigenous peoples deriving from global or regional human rights regimes to which they are not party, particularly when they have emphasised constitutional limitations to the implementation of UNDRIP. ${ }^{76}$

\footnotetext{
${ }^{72}$ Ibid, para 134; referring to Saramaka, para 115.

${ }^{73}$ Saramaka (Merits), para. 194.d; Kaliña and Lokono, para. 305(d); and Kichwa paras. 299-300.

${ }^{74}$ P Birnie, A Boyle \& C Redgwell, International Law and the Environment 626-628 (Oxford University Press, 2009); D Shelton, 'Principle 22: Indigenous People and Sustainable Development' in Jorge Viñuales ed., The Rio Declaration on Environment and Development: A Commentary (Oxford University Press, 2015) 541, 543.

${ }^{75}$ Note, for instance, the continued opposition of some CBD parties to making unequivocal reference to the right to "prior informed consent" of indigenous peoples (eg CBD, Mo'otz Kuxtal voluntary guidelines for the development of mechanisms, legislation or other appropriate initiatives to ensure the "prior informed consent", "free prior informed consent" or "approval and involvement", depending on national circumstances, of indigenous peoples and local communities for accessing their knowledge, innovations and practices, the fair and equitable sharing of benefits arising from the use and application of such knowledge, innovations and practices and for reporting and preventing unauthorized access to such knowledge, innovations and practices, CBD Decision XIII/18, para. 6 (2016)).

${ }^{76}$ E Morgera. Against All Odds: The Contribution of the Convention on Biological Diversity to International Human Rights Law, in Denis Alland et al, eds., Unity and Diversity of International Law (2014) 983. For a recent report of CBD parties' views on importing international human rights law terminology with regard to indigenous peoples, see E Tsioumani et al, "Summary and Analysis of the UN Biodiversity Conference", 9:678 Earth Negotiations Bulletin (ENB) 12-13 (2016).
} 
In addition, the linkage between benefit-sharing and natural resources under the Convention is not immediately obvious. The relevant treaty basis under the CBD is a qualified obligation to "encourage" equitable benefit-sharing from the use of traditional knowledge of indigenous peoples and local communities, ${ }^{77}$ interpreted in combination with the obligation to protect indigenous and local communities' customary sustainable use of biological resources. ${ }^{78}$ The CBD benefit-sharing obligation is thus arguably triggered by the ecosystem stewardship of indigenous peoples and local communities, ${ }^{79}$ which hinges on the intrinsic connection between these communities' knowledge and their natural resources -in other words, the development and transmission of traditional knowledge through the management of traditionally used natural resources. ${ }^{80}$ Such knowledge is thus embodied in traditional lifestyles ${ }^{81}$ that are inextricably linked to natural resources, shared cultural identity and customary rules. ${ }^{82}$ This resonates with the understanding, under international human rights law, of the traditional use of natural resources as "part of a way of life." 83

The reticence of certain CBD State Parties to engage explicitly in human rights questions has resulted in guidance that does not include minimum guarantees or explicit limits to State discretion. This is the most significant blindspot in international biodiversity law. CBD guidance does provide, on the other hand, more detailed, practical guidance on how to implement benefit-sharing in the context of natural resource governance, which fills a gap in international human rights law. CBD

\footnotetext{
${ }^{77} \mathrm{CBD}$ art 8(j). Other provisions in the Convention (notably arts 1 and 15) focus instead on an inter-State notion of benefit-sharing in the specific context of bioprospecting, although in time they have come to be understood also in an intra-State perspective: E Morgera et al, Unraveling the Nagoya Protocol: A Commentary of the Protocol on Access and Benefit-Sharing to the Convention on Biological Diversity (Martinus Nijhoff, 2014), 24-30.

${ }^{78} \mathrm{CBD}$ art $10(\mathrm{c})$.

${ }^{79}$ Principles of the Ecosystem Approach, Decision V/6 (2000), para. 9, and CBD Decision VII/11 (2004), Annex I, annotations to rationale to Principle 4.' This appears to be reflected in the General Assembly, Strategic Framework for the period 2012-2013 (UN Doc. A/65/6/Rev.1), para. 11(24)(b) and for 2014-2015 (UN Doc. A/67/6 (prog 11)), para. 11(16). See discussion in E Morgera, 'Ecosystem and Precautionary Approach' in E Morgera \& J Razzaque, eds., Encyclopedia of Environmental Law: Biodiversity and Nature Protection Law (Edward Elgar, 2017) 70.

${ }^{80}$ In the light of the placement of CBD art 8(j) in the context of in situ conservation (CBD Art 8). J Gibson, 'Community Rights to Culture: The UN Declaration on the Rights of Indigenous Peoples' in Allen and Xanthaki (n 9) 434, at 434-435 ${ }^{81}$ On the basis of the wording of CBD Article 8(j): see definition of traditional knowledge in Akwé: Kon Guidelines (n 53).

${ }^{82}$ See generally B Tobin, Indigenous Peoples, Customary Law and Human Rights: Why Living Law Matters (Routledge, 2014).

${ }^{83}$ Thornberry (n 41), 334 and 353.
} 
guidance focuses on pragmatic considerations underlying benefit-sharing to counterbalance shortterm gains motivating ecosystem degradation, by protecting the stake in conservation for those communities that more closely interact with nature. Benefit-sharing is thus seen as a means to ensure compliance with environmental protection law. ${ }^{84}$ It serves as an incentive for ecosystem stewards' positive contribution to humanity's well-being that derives from the ecosystem services they provide, maintain or restore. ${ }^{85}$ This can arguably be inferred from CBD Parties' consensus on the types of benefit to be shared. First, more elaborate options on monetary benefit-sharing are outlined under the CBD than in international human rights law. They include not only profit-sharing through trust funds, but also licenses with preferential terms, job creation for communities (which find resonance in the Endorois decision of the African Commission ${ }^{86}$ ), and payments for ecosystem services. ${ }^{87}$ In addition, CBD Parties have identified benefits that support indigenous peoples' own economic activities, such as: fostering local enterprises, participating in others' enterprises and projects, offering direct investment opportunities, facilitating access to markets, and supporting the diversification of incomegenerating (economic) opportunities for small and medium-sized businesses. ${ }^{88}$ Further types of benefits have been identified to improve and consolidate the conditions under which ecosystem stewards and traditional knowledge holders develop and maintain their knowledge and practices: information sharing, capacity building, scientific cooperation, or assistance in diversifying management capacities, ${ }^{89}$ as well as the legal recognition for community-based natural resource

\footnotetext{
${ }^{84}$ Addis Ababa Guidelines (n 56), rationale to Principle 4 and operational guideline to Principle 12.

${ }^{85}$ Principles of the Ecosystem Approach (n 79), para 9.

${ }^{86}$ Endorois, para 297.

${ }^{87}$ Akwé: Kon Guidelines (n 52), para. 46. See M Menton and A Bennett, 'PES: Payments for Ecosystem Services and Poverty Alleviation?' and I Porras and N Asquith, 'Scaling-up Conditional Transfers for Environmental Protection and Poverty Alleviation' in K. Schreckenberg et al (eds), Ecosystem Services and Poverty Alleviation: Trade-offs and Governance (Routledge, 2018) 189 and 204 respectively.

${ }^{88}$ CBD, Guidelines on Biodiversity and Tourism, Decision V/25 (2000), paras. 22-23, 43.

${ }^{89}$ Principles of the Ecosystem Approach (n 79), para 9; CBD expanded work programme on forest biodiversity, Decision VI/22 (2002), at goal 5, objective 1, activities; CBD work programme on mountain biodiversity, CBD decision VII/27 (2004), Annex, para. 1.3.7; Akwé: Kon Guidelines (n 23), paras. 40 and 46; Addis Ababa Guidelines (n 56), rationale to Principle 4; CBD, Bonn Guidelines on Access to Genetic Resources and Fair and Equitable Sharing of the Benefits Arising out of Their Utilization, CBD Decision VI/24 (2002) Annex, para. 50.
} 
management and conservation, ${ }^{90}$ the incorporation of traditional knowledge in environmental and socio-cultural impact assessments ${ }^{91}$ and in natural resource management planning. ${ }^{92}$ The rationale of the CBD benefit-sharing obligation can thus also be understood as recognition for past and present contributions of indigenous peoples and local communities to global environmental objectives with a view to ensuring that their traditional practices continue in the future. ${ }^{93}$

Under the CBD, therefore, a variety of economic and non-economic benefits have been identified, amounting to a "menu" that allows for a large margin of discretion in implementation. This contrasts with the general laconicism and emphasis on monetary approaches of international human rights law with regard to benefit-sharing modalities discussed above. A wider choice of benefits could allow taking into account communities' needs, values, and priorities on a case-by-case basis, as required under international human rights law, on the basis of a finer-grained understanding of opportunities within natural resource governance. Equally, however, the menu of benefits reveals the limitation of international biodiversity law: in the absence of specific procedural guarantees and indications of the minimum level of protection, benefit-sharing could be used to impose certain views of development upon indigenous peoples and local communities that could endanger their cultural or physical survival. The main blindspot under the CBD is thus that the absence of procedural guarantees to ensure that benefit-sharing works towards its stated objectives. For instance, under the CBD, participation in decision-making is often seen as one of the possible benefits, ${ }^{94}$ blurring the line between required protection and matters up for contextual negotiations. Additionally, international biodiversity law is agnostic on the need to develop national legislation on benefit-sharing, which is

\footnotetext{
${ }^{90}$ Eg CBD Decision VI/22 (n 89), para. 31 and programme element 1, Goal 4, objective 3; CBD work programme on mountain biodiversity (n 89), paras 2.2.1-2.2.5.

${ }^{91}$ Akwé: Kon Guidelines (n 52), para. 56.

${ }^{92}$ Addis Ababa Guidelines (n 56), operational guidelines to Principle 4; and CBD work programme on forest biodiversity (n 89), para 34. See also Agenda 21 (1992) UN Doc A/CONF.151/26/Rev.1 vol 1, Annex II, para. 15(4)(g) and Johannesburg Plan of Implementation (2002) UN Doc A/CONF.199/20, Resolution 2, para. 44(j).

${ }^{93}$ E Morgera, 'Justice, Equity and Benefit-Sharing Under the Nagoya Protocol to the Convention on Biological Diversity’ 25 Italian Y.B. Int'l L. 113 (2015).

94 The CBD work programme on protected areas, for instance, links the goal of promoting equity and benefit-sharing with engaging communities in participatory planning and governance: $n 52$, paras. 2(1)(3)-2(1)(5).
} 
instead increasingly emphasised under international human rights law as a precondition for avoiding human rights violations. ${ }^{95}$ In effect, it has been documented that indigenous peoples' negotiating position in the context of contractual approaches to benefit-sharing is heavily affected by weak national legal frameworks on their rights. ${ }^{96}$

\section{Further developing a mutually supportive interpretation of fair and equitable benefit- sharing}

One of the reasons for this incipient and one-sided cross-fertilisation may be that benefit-sharing is framed $^{97}$ differently under international human rights law and under the CBD, which may lead to conceptually different, but still potentially compatible, approaches in the two regimes. Under the CBD, legal developments on benefit-sharing have focused on equity considerations, out of concern for those communities that devote their efforts to, and bear the risks of, conservation and sustainable use, while the larger society benefits from these efforts without paying the costs associated with them. ${ }^{98}$ These considerations are generally left as assumptions underlying international biodiversity law, rather than issues directly addressed by it. International human rights lawyers, however, have been sceptical of perceived "unrealistic expectations regarding the conservationist behaviour of indigenous peoples [that] may have detrimental consequences for the recognition and respect of their rights." 99 Criticism has been voiced about opportunities under the CBD to condition the recognition

\footnotetext{
${ }^{95}$ Note reference to legislative, policy or administrative measures in the Nagoya Protocol, although in that context benefit-sharing is specifically related to bioprospecting.

${ }^{96} \mathrm{C}$ O'Faircheallaigh \& T Corbett, 'Indigenous Participation in Environmental Management of Mining Projects: The Role of Negotiated Agreements' (2015) 14 Envtl. Pol. 629, 635.

${ }^{97}$ Morgera (n 20), 356.

${ }^{98}$ Principles of the Ecosystem Approach (n 79), Principle 8.

${ }^{99}$ See Desmet (n 4), 41.
} 
or protection of the rights of indigenous peoples to their compatibility with environmental sustainability. ${ }^{100}$

The CBD text arguably authorises its Parties to depart from existing international human rights obligations in the exceptional cases in which their exercise would cause serious damage to or threaten biodiversity. ${ }^{101}$ Even in these cases, however, this should be understood as an obligation for CBD Parties to negotiate an interpretation of the CBD and other international instruments that leads to the identification of a mutually supportive solution with international human rights law. ${ }^{102}$ The latter understanding has been supported by the most recent case law of the Inter-American Court ${ }^{103}$ recognising the "right to dispose of natural resources should not be interpreted as a freedom to engage in unsustainable uses of the environment. Rather, this right must be understood in the context of common responsibilities for maintaining the health of our ecological systems"104 and in recognition of indigenous peoples as an "important part of the solution." ${ }^{105}$ International human rights law has thus relied on the $\mathrm{CBD}$ as part of a wider normative framework that legitimises the reconciliation of different interests protected internationally. ${ }^{106}$

The full potential for a mutually supportive interpretation will be now explored by piecing together existing sources of authoritative interpretation that have not yet been drawn together by international human rights bodies but are implicitly compatible. First, the proposed interpretation will

\footnotetext{
${ }^{100}$ Ibid, 131-132.

${ }^{101}$ CBD art 22(1).

${ }^{102}$ E Morgera, 'Far Away, So Close: A Legal Analysis of the Increasing Interactions between the Convention on Biological Diversity and Climate Change Law' (2011) 2 Climate Law 85.

${ }^{103}$ Kaliña and Lokono, paras. 181 and 193.

${ }^{104}$ M Fitzmaurice, 'The Question of Indigenous Peoples' Rights: A Time for Reappraisal?' in D French (ed.), Statehood And Self-Determination: Reconciling Tradition And Modernity In International Law (Cambridge University Press, 2013), 361; Desmet (n 4), 186-187; and S Wiessner, 'The Cultural Rights of Indigenous Peoples: Achievements and Continuing Challenges' (2011) 22 EJIL 121.

$105 \mathrm{~J}$ Ife, Human Rights from Below: Achieving Rights through Community Development 151 (Cambridge University Press, 2010). See also increasing references under the CBD to the "contribution of the collective action of indigenous peoples and local communities": CBD COP Decision XIII/3, Strategic actions to enhance the implementation of the Strategic Plan for Biodiversity 2011-2020 and the achievement of the Aichi Biodiversity Targets, including with respect to mainstreaming and the integration of biodiversity within and across sectors, paras 15, 18(b) and 98 (2016) and Decision XIII/ XIII/20. Resource mobilization (2016), paras 18-21 and Annex ('Guiding principles on assessing the contribution of collective action by indigenous peoples and local communities').

${ }^{106}$ R Pavoni, 'Mutual Supportiveness as a Principle of Interpretation and Law-Making: A Watershed for the WTO-andCompeting-Regimes Debate?' (2010) 21 EJIL 649, at 665.
} 
seek to clarify the procedural and substantive dimensions (fairness and equity) of benefit-sharing. It will then proceed to discuss the interplay of benefit-sharing with impact assessments and FPIC, arguing that benefit-sharing is intertwined with consent as an ongoing partnership-building process, and should be distinguished from compensation. The section will conclude with a reflection on the legal status of the international obligation to share benefits at the intersection of the two bodies of international law.

\subsection{Procedural dimensions}

Even in the face of the varying terminology used by different international human rights processes, ${ }^{107}$ former UN Special Rapporteur James Anaya indicated that "the only clear international standard applicable to benefit-sharing [in relation to extractives and indigenous peoples] is that such sharing must be 'fair and equitable'." 108 The focus on fairness and equity under the CBD, for its part, has remained quite inchoate. Fairness and equity in benefit-sharing are assumed, rather than supported by the development of international criteria or monitoring mechanisms. What fairness and equity mean is thus left to be determined through successive (often contractual) negotiations of benefitsharing agreements. ${ }^{109}$ In effect, case-by-case negotiations appear needed for a contextual operationalisation of benefit-sharing under international biodiversity and human rights law, as they both refer (independently of each other) to "mutually agreed" benefits. ${ }^{110}$ Furthering a mutually supportive interpretation of fair and equitable benefit-sharing may thus serve also to set minimum

\footnotetext{
107 There is no such qualification for benefit-sharing in the text of ILO Convention No. 169. The CERD, UNPFII and the Inter-American Court of Human Rights have referred to equitable benefit-sharing: CERD, Concluding Observations on Ecuador (n 48), para. 16 (2003); UNPFII, Report of the International Workshop on Methodologies regard Free, Prior Informed Consent and Indigenous Peoples, UN Doc. E/C.19/2005/3, para. 46(i)(e) (2005); and Saramaka (Merits), para. 140 ("reasonable equitable") and Endorois, paras. 269 and 297.

108 Special Rapporteur Anaya, A/HRC/15/37 (n 29), paras. 67 and 76-78.

${ }^{109}$ F Francioni, 'Equity' in R Wolfrum (ed), Max Planck Encyclopedia of Public International Law (Oxford University Press 2010, online ed), para. 25.

${ }^{110}$ Kaliña and Lokono, paras. 227-229 and 159. See A Lucas, 'Participatory Rights and Strategic Litigation: Benefits Forcing and Endowment Protection in Canadian Natural Resource Development' in L Barrera-Hernandez et al (eds), Sharing the Costs and Benefits of Energy and Resource Activity (Oxford University Press, 2016) 339, at 342-345.
} 
parameters for fairness and equity under international biodiversity law by relying on international human rights law notions. This would be comparable to the evolution of the similarly worded notion of fair and equitable treatment in international investment law, ${ }^{111}$ for which the meaning of 'fair and equitable' was not elaborated upon in the relevant treaties, and gradually fleshed out through international adjudication on the basis of human rights standards such as due process, nondiscrimination, and proportionality. ${ }^{112}$

Along these lines, it can be argued that reference to 'fair and equitable' serves to make explicit both procedural (fairness) and substantive (equity) dimensions of justice. ${ }^{113}$ This argument can then be related to references in both international human rights and biodiversity sources (independently of each other) to the need for benefit-sharing to be endogenously identified and culturally appropriate. ${ }^{114}$ In particular, the Inter-American Court has expressed the view that effective and appropriate measures to secure the use and enjoyment of traditional territories must accord with indigenous and tribal peoples' cultural identity, economic and social characteristics, possible situation of vulnerability, customary laws and special relationship with the land. ${ }^{115}$ The UN Expert Mechanism on Indigenous Peoples' Rights has confirmed that benefit-sharing is expected to accord with communities' own understanding of benefits. ${ }^{116}$ The ILO monitoring bodies have emphasised that benefit-sharing should provide concrete expression of indigenous peoples' accord on the basis of their values, customs and preferences. ${ }^{117}$ These references clearly point to the interactions of procedural and substantive dimensions, and seem to exclude unidirectional and/or top-down flows of benefits

\footnotetext{
111 The suggestion to draw on the evolution of fair and equitable treatment to better understand fair and equitable benefit sharing was put forward by F Francioni, 'International Law for Biotechnology: Basic Principles', in F Francioni and T Scovazzi (eds), Biotechnology and International Law (2006) 3, at 24.

112 PM Dupuy and J Viñuales, 'Human Rights and Investment Disciplines: Integration in Progress', in M Bungenberg et al. (eds), International Investment Law: A Handbook (2015) 1739.

${ }^{113}$ See generally T Franck, Fairness in International Law and Institutions (1995), and reflections by R Klager, Fair and Equitable Treatment in International Investment Law (Cambridge University Press 2013), at 141-152.

${ }^{114}$ Saramaka (Interpretation), paras. 25-2; CBD, Refinement and Elaboration of the Ecosystem Approach (n 79), paras 1(8), 2(1); CBD, Tkarihwaié:ri Code of Ethical Conduct to Ensure Respect for the Cultural and Intellectual Heritage of Indigenous and Local Communities, CBD Decision X/42 (2010), para. 14.

${ }^{115}$ Kaliña and Lokono, para. 251(4).

${ }^{116}$ UN Expert Mechanism (n 5), para. 39(h); also Special Rapporteur Anaya, Report to the General Assembly, UN Doc. A/67/301, para. 78 (2012).

${ }^{117}$ ILO, Observation (Norway) (n 30), 95.
} 
that would be externally imposed and unlikely to satisfy the standard of cultural appropriateness. Rather endogenous identification reinforces the view that benefit-sharing is about supporting community agency ${ }^{118}$ and indigenous peoples' right to self-determination. ${ }^{119}$

The argument put forward here is that sparse interpretative guidance in international biodiversity and human rights instruments seem to indicate that the procedural dimension of benefitsharing is a concerted and dialogic process aimed at developing a genuine partnership between communities and other (generally more powerful) actors based on a common understanding across different worldviews of what economic and non-economic benefits are at stake and how they should be shared. This presupposes an understanding of benefit-sharing as an iterative process, rather than a one-off exercise, of good-faith engagement ${ }^{120}$ providing "elements of confidence-building conducive to consensus." 121 Such an approach would provide an opportunity to develop a shared development vision on the basis of respect for each parties' views and mutual openness to persuasion. ${ }^{122}$ In addition, it needs to factor in communities' evolving perceptions and understanding of benefits over time. ${ }^{123}$ To sum, up, and as agreed upon under the CBD, respectful and enduring partnership-building "means a continual process of building mutually beneficial, ongoing arrangements ... in order to build trust, good relations, mutual understanding, intercultural spaces, knowledge exchanges, and to create new knowledge and reconciliation."124 These are key considerations that can underpin the minimum procedural guarantees spelled out under international human rights law. ${ }^{125}$

\footnotetext{
118 Morgera (n 20), 363-364 and Mancisidor (n 26).

119 Saramaka (Interpretation), paras. 25-2; CBD, Refinement and Elaboration of the Ecosystem Approach (n 79), paras 1(8), 2(1); CBD, Tkarihwaié:ri Code (n 114), para. 14.

${ }^{120}$ Morgera (n 20), 363-364.

${ }^{121}$ Special Rapporteur Anaya, Report on the situation of human rights and fundamental freedoms of indigenous peoples, UN Doc. A/HRC/12/34, para. 53 (2009); and Special Rapporteur Anaya, Study on Extractive Industries and Indigenous Peoples, UN Doc. A/HRC/24/41, para. 88 (2013).

${ }^{122}$ N Craik, 'Process and Reconciliation: Integrating the Duty to Consult with Environmental Assessment' (2016) 52 Osgoode Hall L.J. 1, 42 and 48.

${ }^{123}$ P Keenan, 'Business, Human Rights, and Communities: The Problem of Community Contest in Development', Illinois Public Law Research Paper No. 14-18 (2013), at http://ssrn.com/abstract=2353493.

${ }^{124}$ CBD Mo'otz Kuxtal Guidelines (n 75), para 23(a) and 8.

125 See section 1.1. above.
} 


\subsection{Substantive dimensions}

International sources have shied away from elucidating clearly and explicitly the substantive content of benefit-sharing. Scarce interpretative guidance can be pieced together, however, on the basis of legal theory on equity in international law, the interpretation of the right to development offered by the African Commission and the menu of benefits identified under the CBD.

Legal theory has identified two substantive dimensions of equity in international law. First, no participant can make claims that automatically prevail over the claims made by other participants. ${ }^{126}$ In the specific case of fair and equitable benefit-sharing, this means excluding an overriding presumption in favour of State sovereignty over natural resources. ${ }^{127}$ This argument finds resonance in the references in international human rights materials to the need to establish a genuine partnership through benefit-sharing. Accordingly, notwithstanding different power relations, actors should treat each other as equal ${ }^{128}$ to accommodate State sovereignty over natural sovereignty (and the interests of the entire population over natural resources), on the one hand, and indigenous peoples' self-determination or local communities' self-governance ${ }^{129}$ of the relationship with their land upon which their physical and cultural survival ${ }^{130}$ depends.

The second substantive dimension of equity, according to theories of international law, is that inequalities in substantive outcomes are only justifiable if they provide advantages to all participants. ${ }^{131}$ This argument can in turn be related to the references in human rights jurisprudence on benefit-sharing to the concept of reasonableness ${ }^{132}$ with respect to the need to balance the

\footnotetext{
${ }^{126}$ Klager, (n 113), 163.

${ }^{127}$ C Burke, An Equitable Framework for Humanitarian Intervention 250 (Hart Publishing, 2014).

${ }^{128}$ E.g., Special Rapporteur Anaya, A/HRC/12/34 (n 121), paras. 51 and 53; UNDRIP prembular para. 15 (and H Quane, 'The UN Declaration on the Rights of Indigenous Peoples: New Directions for Self-Determination and Participatory Rights?' in Allen and Xanthaki (n 9) 259, 270 and 276-77); UN Expert Mechanism (n 5), Annex, para. 28; and Report of the High-level Task Force on the Implementation of the Right to Development on its Second Meeting, UN Doc. E/CN.4/2005/WG.18/TF/3, para. 82 (2005).

${ }^{129}$ Fitzmaurice (n 104), 375; and Special Rapporteur Anaya, A/HRC/12/34 (n 121), paras. 53 and 43(b).

${ }^{130}$ Saramaka (Interpretation), para. 2

${ }^{131}$ Klager (n 113), 145.

132 O Corten, 'Reasonableness in International Law' in Wolfrum (n 109). See also Reports of the Committee on Economic, Social and Cultural Rights for the Forty-Second and Forty-Third sessions, Consideration of reports of States parties: Cambodia, UN Doc. E/C.12/2009/3, para. 193 (2009), and for the Forty-Second and Forty-Third sessions, Consideration of reports of States parties: Democratic Republic of Congo, UN Doc. E/C.12/2009/3, para. 289 (2009);
} 
protection of the traditional way of life of indigenous peoples that is intimately intertwined with and dependent on natural resources. ${ }^{133}$ Regional human rights jurisprudence has indicated that benefitsharing from natural resource exploitation should be in accordance with communities' determinations based on their customs and traditions, while taking into account proportionality vis-à-vis the public interest, including environmental protection. ${ }^{134}$ In the case of conservation measures, in particular, the Inter-American Court has indicated that it may be "reasonable" for the State to retain supervision, access and management of areas of general and strategic interest and for safety reasons. ${ }^{135}$ The same concerns appear implicitly reflected in CBD guidance related to the respect of communities' customary laws and practices ${ }^{136}$ and benefits in the form of co-management of natural resources. ${ }^{137}$ The proportionality test, however, according to Århén, should not to be conceived merely according to the understanding of the majority of the population (likely influenced by market value) but also in terms of indigenous understanding of its cultural and spiritual value, to avoid discrimination against different worldviews. ${ }^{138}$

These considerations will now be related to guidance on benefit-sharing provided by the African Commission. The Endorois decision is the only international material that focuses on the substantive dimensions of benefit-sharing in relation to the right to development. ${ }^{139}$ The Commission

\footnotetext{
OHCHR, Mapping Human Rights Obligations Relating to the Enjoyment of a Safe, Clean, Healthy and Sustainable Environment: Individual Report on the International Covenant on Economic, Social and Cultural Rights (2013), para. 48 (2013) and Report on the Rights of Indigenous Peoples (n 47), paras. 45-46; and 1993 Vienna Declaration and Programme on Action, UN Doc. A/CONF.157/23, part I, para. 20 (1993).

${ }^{133}$ Endorois, para. 15.

${ }^{134}$ IACtHR, Comunidad Garifuna de Punta Piedra y sus miembros vs Honduras (Preliminary Exceptions, Merits, Reparations and Costs), 8 October 2015, para. 215; Kaliña and Lokono, para. 168.

${ }^{135}$ Kaliña and Lokono, para. 191.

${ }^{136}$ Gibson (n 80), 450.

${ }^{137}$ CBD work programme on protected areas (n 52), para 19; Addis Ababa Guidelines (n 56), practical principle 12, operational guidelines.

${ }^{138}$ Endorois, para. 212. Århén (n 5), at 207-212.

${ }^{139}$ Endorois, para. 294-298. The right to development is explicitly protected under the African Charter (art. 22), and is understood as an expression of the right to self-determination of indigenous and tribal peoples comprising a distinctive bundle of rights to participation, culture and natural resources: see Pentassuglia (n 38), 157, and generally and C Doyle \& J Gilbert, 'Indigenous Peoples and Globalization: From "Development Aggression" to "Self-Determined Development”' (2008/9) 7 Eur. Y.B. Minority Issues 219.
} 
clarified the substantive core of benefit-sharing as a matter of choice and increased capabilities, ${ }^{140}$ resulting in indigenous and tribal peoples' improved well-being ${ }^{141}$ and empowerment. ${ }^{142}$ Arguably Special Rapporteur Anaya shed light in a similar way on the substantive elements of benefit-sharing, when he referred to empowerment both in procedural and substantive terms. ${ }^{143}$ This line of reasoning, in as far as it is based on global human rights instruments, ${ }^{144}$ can be relevant under other regional regimes ${ }^{145}$ and globally. ${ }^{146}$

The African Commission, however, did not elaborate on how the substantive dimensions of benefit-sharing could be realised. ${ }^{147}$ The argument put forward here is that choice and capabilities find resonance in the range of monetary and non-monetary benefits that have been identified under the CBD. Choice can be realised through those benefits that provide or enhance "resource control" the realization of communities' worldview of their resources. ${ }^{148}$ Control-benefits can thus take the form of community-based management of natural resources, joint ventures when the skills or technology of external actors may be needed, but also the incorporation of traditional knowledge in environmental and socio-cultural impact assessments and in natural resource management planning,

\footnotetext{
${ }^{140}$ Endorois, para. 279. C Morel, 'From Theory to Practice: Holistic Strategies for Effective Advocacy' in Lennox and Short (n 17) 355, 359. S Coulthard, J. McGregor and C White, 'Multiple Dimensions of Wellbeing in Practice' in Schreckenberg et al (n 87) 243.

${ }^{141}$ J Castellino, 'Indigenous Rights and the Right to Development: Emerging Synergies or Collusion?' in Allen and Xanthaki (n 9) 367, 369 fn 8. On wellbeing as the substantive aim of benefit-sharing, see also Report of the Special Rapporteur in the Field of Cultural Rights: The Right to Enjoy the Benefits of Scientific Progress and Its Applications, UN Doc. A/HRC/20/26, para. 22 (2012); and ILO Conference 87 $7^{\text {th }}$ Session 1999, Report III (Part 1a), 434.

${ }^{142}$ Endorois, para. 283, as well as paras. 127-129 and 135. See, however, words of caution again understanding of wellbeing in economic and spatial terms, rather than cultural terms, by Thornberry (n 41), 298.

$143 \mathrm{~A} / \mathrm{HRC} / 24 / 41$ (n 121), paras. 75 and 59.

${ }^{144}$ Endorois, paras. 294 and 296; CERD, General Recommendation No. 23: Indigenous Peoples, UN Doc. A/52/18, annex V, para. 4 (1997); CERD, Concluding Observations on Ecuador, UN Doc. A/58/18, para. 62 (2003).

${ }^{145}$ M Orellana, 'Saramaka People v Suriname Judgment' (2008) 102 AJIL 841, 846. Although note limited crossfertilization between the Inter-American and European courts of human rights: see generally R Pavoni, 'Environmental Jurisprudence of the European and Inter-American Courts of Human Rights: Comparative Insights' in B Boer (ed), Environmental Law Dimensions of Human Rights (Oxford University Press, 2015) 69, 105.

${ }^{146}$ On the "glocalization" of right to development, see R Stavenhagen, 'Making the Declaration on the Rights of Indigenous Peoples Work: The Challenge Ahead' in Allen and Xanthaki (n 9) 147, 152-153. See also Pentassuglia (n 18), 201.

${ }^{147}$ K Sing' Oei \& J Shepherd, 'In Land We Trust': The Endorois' Communication and the Quest for Indigenous Peoples' Rights in Africa' (2010) 16 Buff. Hum. Rts. L. Rev. 57, 108-109.

${ }^{148}$ For their own primary benefit, including in terms of environmental sustainability, albeit without excluding opportunities for benefits to others according to views of broader society: see generally Y Omorogbe, 'Resource Control and Benefit-sharing in Nigeria' in Barrera-Hernandez et al (n 110).
} 
and, under certain conditions, the allocation of employment opportunities in the natural resource sector to communities. Capabilities as the distribution of opportunities for individuals and groups to freely pursue their chosen way of life and wellbeing, ${ }^{149}$ find specific reflection in support-benefits identified under the CBD. These include support for the economic activities of indigenous peoples and local communities, through direct investment opportunities, access to markets, and diversification of income-generating (economic) opportunities, or capacity building and technical support. This proposed distinction between benefits fundamentally geared to protect or enhance communities' control over natural resources (and thereby enhancing choice).

This could also address possibly redress of past injustices, and benefits providing support (and thereby enhancing capabilities) for the exercise of effective control, is not explicitly discussed under the CBD. The corollary to the argument proposed here is that both types of benefits are essential. On the one hand, support-benefits are extremely significant in their own right to prevent further marginalization of community voices due to the intricate nature of environmental management processes in which their views and preferences are to be integrated. ${ }^{150}$ For instance, communities may be legally recognised full management of an area, but not supported in complying with highly technical aspects of applicable legislation, such as plant health requirements. On the other hand, the absence of an explicit discussion of such distinction under the CBD carries the risk that supportbenefits may be offered as an alternative, rather than as a complement, to control-benefits: for instance, communities may be offered employment opportunities, but not a seat at the decisionmaking table of a forestry project or protected area. ${ }^{151}$

A fully-fledged mutually supportive interpretation could guide the identification of appropriate benefits in a particular context by recognising the need for both control-benefits and

\footnotetext{
${ }^{149}$ Eg generally M Nussbaum \& A Sen, The Quality of Life (Clarendon Press, 1993).

${ }^{150}$ Shelton (n 74), 554.

${ }^{151}$ Note the mixed picture arising in this regard from benefit-sharing as part of community-based wildlife management initiatives in Africa. F Nelson, 'Introduction' in F Nelson (ed.), Community Rights, Conservation and Contested Lands: The Politics of Natural Resource Governance in Africa (Earthscan, 2010) 3, 4 and 11.
} 
support-benefits in realising the objective of furthering communities' own development priorities ${ }^{152}$ and the full realization of their human rights as a form of reasonable partnership.

\subsection{Benefit-sharing and impact assessment}

International human rights processes have been quite consistent in establishing that prior, comprehensive environmental and socio-cultural impact assessments be carried out as a safeguard for indigenous and tribal peoples' rights over their natural resources. This section explores how a mutually supportive interpretation of international biodiversity and human rights standards can clarify the interplay between benefit-sharing and impact assessments. The proposed interpretation illuminates opportunities to engender a proactive approach to the protection and realization of human rights by supporting understanding of different worldviews. The proposed interpretation builds upon a detailed interrogation of the CBD Akwé: Kon Guidelines, and is informed by a consideration of well-known implementation challenges in the environmental field, and of the status, justiciability and minimum content of impact assessment obligations under general international law.

Impact assessments are generally understood as geared towards damage prevention or damage control, including as a way to provide information necessary for indigenous peoples to decide whether to provide FPIC or not. ${ }^{153}$ For instance, the Inter-American Court has consistently indicated that these assessments should aim at ensuring that permitted levels of impact do not negate the survival of the members of indigenous peoples, and that indigenous peoples are aware of possible risks, including environmental and health ones, so that they can weigh up whether to accept proposed

\footnotetext{
${ }^{152}$ Special Rapporteur on the human rights obligations related to environmentally sound management and disposal of hazardous substances and waste, Report, (2012) UN Doc. A/HRC/21/48, paras. 36 and 69(h).

${ }^{153}$ N Craik, 'Biodiversity-inclusive Impact Assessment' in Morgera and Razzaque (n 79) 431, argues that consideration of biodiversity concerns more generally expands the range of issues and values to be included in environmental assessments. See also C Doyle, Indigenous Peoples, Title to Territory, Rights and Resources: The Transformative Role of Free, Prior and Informed Consent (Routledge, 2015), 94.
} 
developments voluntarily and with full knowledge. ${ }^{154}$ A mutually supportive interpretation, instead, unveils the potential of the early consideration of culturally appropriate and endogenously defined benefitsharing options are part of impact assessment expands the scope and approach of the latter quite significantly. The CBD Akwé: Kon Guidelines specifically clarify that impact assessments should identify, in an integrated fashion - that is, at least potentially in accordance with holistic worldviews - environmental, economic and socio-cultural benefits, ${ }^{155}$ in addition to potential damage to ways of life, livelihoods, well-being, and traditional knowledge. ${ }^{156}$ In supporting FPIC processes, ${ }^{157}$ the CBD Akwé: Kon Guidelines require that consideration of benefit-sharing starts significantly early on in the process - as early as the screening and scoping phases of assessments. ${ }^{158}$ As a result, the Akwé: Kon Guidelines move away from a damage-control approach, shifting to collaboratively identifying and understanding also opportunities for positive impacts according to indigenous peoples' and local communities' worldviews ${ }^{159}$ to determine the scope of the assessment.

The Akwé: Kon Guidelines, furthermore, arguably move away from a technocratic exercise, calling for collaborative procedures and methodologies aimed at ensuring the full involvement of indigenous peoples and local communities. As it has been poignantly remarked, the general effectiveness of environmental assessments "as procedural measures generating environmentally sound and just outcomes in socio-ecological systems characterised by uncertainty and normative disagreement" remains "an open question, notwithstanding over forty years of practice across the globe." ${ }^{160}$ In particular, while participation of potentially affected stakeholders is a widely accepted and essential element of environmental assessment, ${ }^{161}$ the actual suitability of this tool and of settled assessment practices in different countries to effectively and respectfully integrate traditional

\footnotetext{
${ }^{154}$ Saramaka (Merits), para. 133; Kichwa, para. 205; Kaliña and Lokono, para. 214.

${ }^{155}$ Akwé: Kon Guidelines (n 52), para. 23.

${ }^{156}$ Ibid, para. 36.

${ }^{157} \mathrm{Ibid}$, paras. 8(e) and 53.

${ }^{158} \mathrm{Ibid}$, Forward, and para. 3, and 13-14.

159 Ibid, para. 37.

${ }^{160}$ See Craik (n 153) 443.

${ }^{161}$ Rio Principles 10 and 22; International Law Commission, Draft Articles on the Prevention of Transboundary Harm from Hazardous Activities, (2001) UN Doc A/56/1, Ch 5.E, art 13; Independent Expert Knox, Mapping Report (n 40).
} 
knowledge with "scientific knowledge,"162 remains to be explored. In addition, evidence confirms that EIAs may not provide a culturally appropriate and open space for understanding the worldviews of indigenous peoples, due to embedded tendencies in EIA practice to privilege mainstream views of development. This may explain indigenous peoples' preference for indigenous assessments that are fully based on indigenous laws and legal traditions. ${ }^{163}$

Consequently, according to the Akwé: Kon Guidelines, the breadth of the assessment ranges from cultural elements such as belief systems, languages and customs, ${ }^{164}$ to systems of natural resource use, the maintenance of genetic diversity through indigenous customary management, the exercise of customary laws regarding land tenure and distribution of resources and benefits, ${ }^{165}$ food and health, ${ }^{166}$ community well-being, vitality and viability (employment levels and opportunities, welfare, education, and availability and standards of housing, infrastructure, services), ${ }^{167}$ as well as transgenerational aspects, such as opportunities for elders to pass on their knowledge to youth. ${ }^{168}$ Governments are also expected to take into account indigenous peoples and local communities' rights over lands and waters traditionally occupied or used by them and associated biodiversity. ${ }^{169}$ The Akwé: Kon Guidelines further call for caution on the risks of elite capture ${ }^{170}$ associated with benefitsharing: they draw attention to the "affected community and its people as a whole" so as to ensure that "particular individuals or groups are not unjustly advantaged or disadvantaged to the detriment of the community as a result of the development." 171 Overall, the range of considerations to be integrated in otherwise technical, information-focused assessment exercises emerge as an essential

\footnotetext{
162 S Vermeylen et al, 'Intellectual Property, Rights Systems and the Assemblage of Local Knowledge Systems' (2008) 15 Int'l J. Cultural Prop. 201.

163 N Schabus, 'Traditional Knowledge' in Morgera and Razzaque (n 79), 264.

164 Akwé: Kon Guidelines (n 52), para 6(f).

${ }^{165} \mathrm{Ibid}$, paras 24 and 27-28, 34.

166 Ibid, para. 42.

${ }^{167}$ Ibid, para. 6(d).

168 Ibid, para. 49.

${ }^{169}$ Ibid, para. 57.

${ }^{170}$ Keenan (n 123).

${ }^{171}$ Akwé: Kon Guidelines (n 52), para. 51.
} 
pre-condition to realise the transformational potential of impact assessments to develop a shared development vision informed by communities' worldviews. ${ }^{172}$

As Craik has pointed out, the analysis of alternatives in environmental assessments is essential to demonstrate good faith and the meaningful character of consultations in the absence of clear quantitative standards to assess the acceptability of impacts. ${ }^{173}$ Authorities must demonstrate that mitigation measures, at a minimum, correspond to the preferred alternatives put forward by indigenous peoples or local communities, including when it is an alternative to the project, rather than just alternative means of carrying out the proposed project. Should a different alternative be chosen, authorities' justification also needs to take into account indigenous peoples' views. ${ }^{174}$

The practical relevance of a mutually supportive interpretation of environmental assessment obligations rests not only on the broad intergovernmental support for the CBD Guidelines, but also on the lessons learnt in the environmental domain with regard to the transformative potential of environmental assessments and the challenges to its realization. Different national frameworks on environmental assessments may be more or less suited to protect the rights of indigenous peoples and local communities, as the balancing of different interests may depend on whether constitutional protection is afforded to indigenous rights and/or to the general interest in environmental protection. ${ }^{175}$ While the International Court of Justice (ICJ) left the determination of the precise requirements of an EIA to the State's discretion, ${ }^{176}$ it has been argued that at least two components of impact assessments are required by general international law - cumulative impact assessments and post-project monitoring. ${ }^{177}$ Both can have an important role to play in the protection and realization of indigenous peoples' and local communities' natural resource-related rights, ${ }^{178}$ in particular with

\footnotetext{
172 On such a transformational potential of impact assessment, see generally Craik (n 122).

${ }^{173}$ N Craik, H Gardner and D McCarthy, 'Indigenous - Corporate Private Governance and Legitimacy: Lessons Learned from Impact and Benefit Agreements’ (2017) 52 Resources Policy 379.

${ }^{174}$ Ibid.

${ }^{175}$ See generally Craik et al (n 173); and also Desmet (n 4), 186-187. Note, however, Birnie et al (n 74 ), 287.

176 Pulp Mills on the River Uruguay (Argentina v Uruguay), ICJ 20 April 2010, para. 205.

${ }^{177}$ N Craik, 'Principle 17: Environmental Impact Assessment' in Viñuales (n 74) 451, 460.

${ }^{178} \mathrm{M}$ Barelli, 'Free, Prior and Informed Consent in the Aftermath of the UN Declaration on the Rights of Indigenous Peoples: Developments and Challenges Ahead' (2012) 16 Int'l J. Hum. Rts. 1, 15. See, eg, HRC, Jouni E. Länsman et al. v. Finland, Communication No. 671/1995, U.N. Doc. CCPR/C/58/D/671/1995 (1996), para 10.7.
} 
regard to an iterative process of identification and sharing of benefits, as the understanding of impacts evolve. For instance, a benefit-sharing arrangement in the context of the cultivation of a unique variety of rice may initially revolve around production sharing between the community that has been the custodian of this variety and of the lands where it is traditionally cultivated and a State-subsidised company that conducts agricultural activities to relieve aging or otherwise economically active members of the community. Over time, however, the community may realise that creating seed nurseries and avoiding the use of chemicals that may damage other traditional land uses is equally significant for the partnership than production sharing.

Finally, the prevailing practice in project-level environmental assessments does not include consideration of relevant historical context ${ }^{179}$ and land claims, and is less likely to address long-term implications of resource development on community interests. International environmental law rather has recourse to strategic environmental assessments, at the level of policies, plans, and programmes, to take into account cumulative impacts. Human rights bodies should therefore give consideration, in order to support consideration of communities' broader territorial and historical perspectives, ${ }^{180}$ to States' obligations to carry out strategic environmental assessments, which is not a common requirement outside of Europe, ${ }^{181}$ even if it is a general requirement in international law ${ }^{182}$ and consensus guidance has been developed under the CBD. ${ }^{183}$

\subsection{Benefit-sharing and FPIC}

This section further develops a mutually supportive interpretation of benefit-sharing as intertwined with FPIC, rather than as a subsequent step to FPIC. The discussion serves to identify areas of overlap between FPIC and benefit-sharing as iterative dialogic processes that are aimed not only at the

\footnotetext{
179 S Vermeylen, "Benefit-sharing, Justice and the Global South" BENELEX blog post (April 2016).

${ }^{180}$ See generally Craik et al (n 173).

${ }^{181}$ Craik (n 153) 437-438.

${ }^{182} \mathrm{~N} 177$.

${ }^{183}$ CBD art 14(2).
} 
protection, but also at the realization of indigenous peoples' rights over natural resources. In other words, a more developed mutually supportive interpretation helps move away from conceptualising FPIC and benefit-sharing merely as safeguards, so as to consider them proactive tools for the full realization of indigenous peoples' rights. In addition, this section explores the contribution of CBD materials to the elucidation of the procedural and substantive content of FPIC, and the contribution of international human rights law to the identification of additional guarantees required for FPIC and benefit-sharing. Ultimately, the discussion serves to clarify that lack of fair and equitable benefitsharing can provide legitimate grounds to withhold or withdraw consent.

Although it is commonly considered a relatively recent international legal concept, ${ }^{184}$ prior informed consent has originated in indigenous peoples' own legal traditions and relations with other peoples. ${ }^{185}$ In the context of international human rights processes, FPIC has been interpreted as entailing that consent should be given freely, without coercion, intimidation or manipulation. States are to allow sufficient time for internal discussion within the community, ${ }^{186}$ seeking FPIC whenever there is a possible impact on traditional life ${ }^{187}$ at all stages of development projects or conservation initiatives (from inception to final authorization and implementation). ${ }^{188}$ State obligations thus include to create channels for sustained, effective and reliable dialogue with indigenous peoples' representative institutions. ${ }^{189}$

FPIC encounters varied degrees of recognition or commitment among States. ${ }^{190}$ Under the CBD, while the Akwé: Kon Guidelines refer to "prior informed consent,"191 more recent

\footnotetext{
${ }^{184}$ E.g. UN Expert Mechanism, Final report of the study on indigenous peoples and the right to participate in decisionmaking, UN Doc A/HRC/18/42, 2011, para. 63, criticized by Doyle (n 153), 5.

${ }^{185}$ See generally Doyle (n 153).

${ }^{186}$ Kichwa, para. 180.

${ }^{187}$ Kaliña and Lokono, Joint Concurring Opinion of Judges Sierra Porto and Ferrer Mac-Gregor Poisot, paras. 14; UNPFII, Report on the tenth session, UN Doc E/2011/43-E/C.19/2011/14, paras. 34-38 (2011), particularly para. 34.

${ }^{188}$ Kaliña and Lokono, Joint Concurring Opinion of Judges Sierra Porto and Ferrer Mac-Gregor Poisot, para. 14.

${ }^{189}$ Kichwa, paras. 166 and 177; Endorois, para. 289; Kaliña and Lokono, Joint Concurring Opinion of Antonio Sierra Porto and Mac-Gregor Poisot, para. 15.

${ }^{190}$ Gilbert \& Doyle (n 9), 325.

${ }^{191}$ Akwé: Kon Guidelines (n 52, paras. 29, 52-53 and 60) refer consistently only to 'prior informed consent'.
} 
instruments ${ }^{192}$ refer to "prior informed consent or approval and involvement" reflecting the reluctance by some CBD Parties to fully endorse the standards enshrined in UNDRIP. According to proponent countries, the expression "approval and involvement" was introduced in order to allow for a greater degree of flexibility in implementation at the national level, ${ }^{193}$ in the light of different domestic legal arrangements concerning the relations between governments and indigenous peoples within their territories. ${ }^{194}$ It can be hypothesised that these differences mainly concern the ways and degree to which the FPIC process is determined and controlled by indigenous communities. ${ }^{195}$ Several commentators have suggested that CBD Parties can consider the two expressions as having essentially the same meaning in practice, ${ }^{196}$ that is effectively empowering communities to genuinely influence decisions that affect their interests, ${ }^{197}$ not merely a right to be involved in such processes. ${ }^{198}$

In effect, the dividing line between the general principle of international law on effective consultation and FPIC obligations is not clear-cut. The Inter-American Court emphasised the need for "special and differentiated" consultation processes when the interests of indigenous and tribal peoples may be affected, ${ }^{199}$ with the public interest test set at a higher threshold because their physical and cultural survival is at stake. ${ }^{200}$ In other words, FPIC goes beyond a more general right to

\footnotetext{
192 Nagoya Protocol art 6(2), with "approval and involvement" being found in the wording of CBD art 8(j); Bonn Guidelines (n 89), para. 31; and CBD Decision V/16, para. 5. For an indication of continued diverge of views on utilising UNDRIP language in the context of the CBD, see C Benson et al, Summary of the Seventh Meeting of the Working Group on Article 8(j), 9:557 ENB (2011) 5-6; and B Antonich et al, Summary of the Eighth Meeting of the Working Group on Article 8(j) and 17th Meeting of the Subsidiary Body on Scientific, Technical and Technological Advice of the Convention on Biological Diversity, 9:611 ENB (2013), 4, 6-7 and 20.

${ }^{193}$ G Burton, 'Implementation of the Nagoya Protocol in JUSCANZ Countries: The Unlikely Lot' in Morgera et al (eds), The 2010 Nagoya Protocol on Access and Benefit-Sharing in Perspective: Implications for International Law and Implementation Challenges (Martinus Nijhoff, 2013) 295, 318, particularly 318-319.

194 "Joint submission Grand Council of the Crees (Eeyou Istchee)," 133-136, and comments by A Savaresi, 'The International Human Rights Law Implications of the Nagoya Protocol' in Morgera et al (n 193) 53, 69; Special Rapporteur Anaya, A/67/301 (n 116), paras. 58-59.

195 Special Rapporteur Anaya, A/HRC/24/41 (n 121), paras. 26-36.

${ }^{196}$ Eg S Nijar, The Nagoya Protocol On Access And Benefit Sharing: An Analysis, (2011); and Special Rapporteur Anaya, A/67/301 (n 116), paras. 92 and 61, where the Special Rapporteur specifically expresses the 'hopeful expectation' that the provisions of the Nagoya Protocol will be implemented 'in harmony with' UNDRIP.

${ }^{197}$ Doyle (n 153), 154; Thornberry (n 41), 349.

${ }^{198}$ Expert Mechanism on the Rights of Indigenous Peoples, Advice No. 2, Indigenous peoples and the right to participate in decision-making, (2011), para. 1, emphasis added. Århén (n 5), 141.

${ }^{199}$ Kichwa, paras. 165-166.

${ }^{200}$ Endorois, para. 212. Compare with K Gover, 'Settler-State Political Theory, 'CANZUS' and the UN Declaration on the Rights of Indigenous Peoples’ (2015) 26 Eur. J. Int'l L. 345, 372.
} 
consultation with the public, as a matter of intensity of the duty. ${ }^{201}$ FPIC should arguably guarantee a "distinguishable voice" for indigenous and tribal peoples within a pluralistic and democratic society in light of their right to decide their own development priorities. ${ }^{202}$ Other international legal materials have recognised FPIC as part of the human rights of non-indigenous communities. ${ }^{203}$

A key question regards the need to ensure that consent is given by the legitimate representatives of the peoples or communities concerned. International human rights materials emphasise the need to take into account indigenous peoples' and local communities' "self-chosen and autonomously managed"204 decision-making mechanisms, ${ }^{205}$ although FPIC "does not necessarily require unanimity and may be achieved even when individuals or groups within the community explicitly disagree." 206 Accordingly, States are responsible to ensure the genuine involvement of legitimate representatives of indigenous peoples and the true nature of consent in the context of customary institutions, taking into account that consent may be withdrawn at a later stage. $^{207}$

Consensus guidance under the CBD have provided further insights on the "prior" and "free" components of FPIC as a continual process building mutually beneficial, ongoing arrangements ${ }^{208}$ that should be free from "expectations or timelines that are externally imposed." 209 This formulation provides for an additional layer of protection to the western notion of consent as merely devoid of

\footnotetext{
${ }^{201}$ See contra, the argument that the right to consultation is procedural, whereas FPIC as a core element of the internal aspect of the right to self-determination is substantive (the right to effectively determine the material outcome of decision-making process): see Århén (n 5), 135-138. The present author is rather persuaded that procedural and substantive dimensions are intertwined in consultation as well as in FPIC, impact assessment and benefit-sharing. ${ }^{202}$ In light of ILO Convention 169, Article art 7(1): A Fuentes, 'Judicial Interpretation and Indigenous Peoples' Rights to Lands, Participation and Consultation. The Inter-American Court of Human Rights' Approach' (2015) 23 Int'l J. Minority \& Group Rts 39, 74-76 and 79.

${ }^{203}$ Eg Special Rapporteur De Schutter, Interim Report, UN Doc. A/67/268, para. 39 (2012); ECOWAS, Directive on the Harmonization of Guiding Principles and Policies in the mining Sector (2009); UN-REDD Programme, "Guidelines on Free, Prior and Informed Consent" (2013), 11-12; Roundtable on Sustainable Biofuels, Principles and Criteria (2012): Morgera et al (n 77), 40; and L Cotula and K Tienhaara, 'Reconfiguring Investment Contracts to Promote Sustainable Development' (2013) 2011-2012 Y.B. Int'l L. Inv. \& Pol'y 281, 301 and 303.

${ }^{204}$ Doyle (n 154), 16.

${ }^{205}$ Ibid, 154; see Thornberry (n 41), 349.

${ }^{206}$ UNGA Res 17/4, para. 11 (2011).

${ }^{207} \mathrm{Ibid}$.

${ }^{208}$ CBD, Mo'otz Kuxtal guidelines (n 75), para. 6.

${ }^{209} \mathrm{Ibid}$, para 14.
} 
more obvious forms of pressure, such as coercion and intimidation, and benefitted from indigenous representatives' inputs into intergovernmental negotiations. ${ }^{210}$ In addition, this formulation fleshes out the characterization of FPIC as a "constant process of dialogue" advanced in the Inter-American context, ${ }^{211}$ and resonates with the description of benefit-sharing as an interactive process. Because of these shared procedural characteristics and the substantive connection between the objectives of FPIC and a culturally appropriate and endogenously identified benefit-sharing, the two should be seen as intertwined, rather than successive elements of human rights related to natural resources. ${ }^{212}$

With regard to the "informed" dimension of FPIC, international human rights bodies have also clarified that FPIC should be based on an understanding of the full range of issues and implications entailed by the activity or decision in question. As discussed above, the relationship between FPIC and impact assessment has been explored by human rights bodies with a view to providing indigenous peoples with "full and objective information about all aspects of the project that will affect them, including the impact of the project on their lives and environment". ${ }^{213}$ As highlighted with regard to the interface between impact assessment and benefit-sharing, the assessment needs to focus not only on negative impacts but also on positive ones, that have been identified by indigenous peoples and local communities according to their worldviews. Thus, the interplay between impact assessments and benefit-sharing appears as an essential precondition for FPIC to serve not only as a tool to prevent unwanted development, but also to ensure that "indigenous peoples shape developments by and for themselves," 214 providing "the foundations for the emergence of a new resource governance model" premised on the notion of partnership. ${ }^{215}$

In addition, international law provides limited guidance on when the will of States should not

\footnotetext{
210 See generally Morgera (n 76).

${ }^{211}$ Kaliña and Lokono, Joint Concurring Opinion of Judges Sierra Porto and Ferrer Mac-Gregor Poisot.

${ }^{212} \mathrm{~N} 124$ above.

213 See Saramaka (Merits), para. 134; and Fodella (n 23), 356 and 360.

${ }^{214}$ Doyle (n 153), 131.

${ }^{215}$ See generally Doyle (n 153) and V Tauli-Corpuz, "The Concept of Indigenous Peoples' Self-Determined Development or Development with Identity and Culture: Challenges and Trajectories”, UN Doc.

CLT/CPD/CPO/2008/IPS/02, 2008
} 
prevail over that of indigenous and tribal peoples in case of lack of agreement. ${ }^{216}$ So, how to reconcile self-determination that applies to the whole State populations with self-determination of indigenous peoples, ${ }^{217}$ neither of which is absolute? ${ }^{218}$ This boils down to the right of saying "no" by indigenous peoples, in consideration of other human rights at stake of the larger population. To some extent, this can be explained by the need to address these questions in a specific context. But it has led to the thorny question of whether FPIC provides an absolute veto power to right-holding communities. ${ }^{219}$ Several international human rights bodies have excluded that FPIC requires necessarily agreement by indigenous peoples in all circumstances, although consultations should be carried out in good faith and in a form appropriate to the circumstances with the objective of achieving agreement. ${ }^{220}$ Every effort is expected to be made to build consensus on the part of all concerned in reaching an agreement (including on benefit-sharing) that is seen as legitimate by the community, ${ }^{221}$ in line with customary legal traditions. ${ }^{222}$ Particular difficulties arise in situations where ownership over natural resources is not clarified in domestic frameworks, or when consultations with communities in this regard are inconclusive.

On the basis of the interface between impact assessment, FPIC and benefit-sharing in relation to indigenous peoples' rights to natural resources, the argument is put forward here that indigenous and tribal peoples, and possibly other communities, should be legitimately entitled to say "no" to proposed extractive operations or the creation of protected areas in the following circumstances. First, if the proposed activity is likely to affect traditionally owned or used resources, or has the potential to negatively impact on traditionally used resources threatening the community's cultural and

\footnotetext{
216 Århén (n 5), 225.

217 Gilbert \& Doyle (n 9), 313-15 and Tauli-Corpuz (n 215).

218 Århén (n 5), 138.

${ }^{219}$ UN Expert Mechanism, Advice No 2 (n 198), para 23. Gilbert \& Doyle (n 9), 316; Thornberry (n 41 ), 217 and 349 ; Doyle (n 154), 98-99; and M Barelli, 'Development Projects and Indigenous Peoples' Land: Defining the Scope of Free, Prior and Informed Consent' in Lennox and Short (n 17) 69, 75.

${ }^{220}$ Endorois, para. 289; Anaya A/HRC/12/34 (n 121), para 46. On the lack of a unified approach to FPIC at the international level, see Barelli (n 219), 75.

${ }^{221}$ Special Rapporteur Anaya, A/HRC/12/34 (n 121), para. 53.

${ }^{222}$ Which are considered premised on principles of good faith, justice, friendship and solidarity, as a notion that affirms and protects the rights of both parties and clarify their duties towards one another: Doyle (n 153), 41.
} 
physical survival. ${ }^{223}$ Second, if an early, genuine and culturally appropriate identification and discussion of benefits according to their worldviews has not been undertaken at all; or has not had any impact on the final outcome, in the absence of sufficient reasons to justify such an outcome. Without early and genuine discussion of benefit-sharing, the State would not be able to prove that the decision is "consistent with the full range of applicable international norms," ${ }^{224}$ when communities" culture, society and way of life are at stake. ${ }^{225}$

\subsection{Benefit-sharing and compensation}

As discussed above, under the CBD benefit-sharing has been interpreted as a reward and incentive for the good management practices of indigenous peoples and local communities that are responsible for the production and sustainable management of ecosystem functions. ${ }^{226}$ Occasional references to indigenous peoples' ecosystem stewardship can also be found in international human rights law materials. ${ }^{227}$ But principally, under international human rights law, benefit-sharing has been conceptualised as a form of compensation. ${ }^{228}$ This may be a consequence of the emphasis on damage prevention and control in impact assessments, and on financial payments in benefit-sharing agreements. Nevertheless, the Inter-American Court's reliance on benefit-sharing has been considered "promising" in increasingly focusing on indigenous peoples' preferences, being deployed in accordance with their modes of governance, and empowering victims, while being more efficient and less expensive in its non-monetary form. ${ }^{229}$ This section discusses how a fully-fledged mutually

\footnotetext{
${ }^{223} \mathrm{Ibid}$, at 8. See also ILA, Report on the Rights of Indigenous Peoples (2010).

224 J Anaya, Indigenous Peoples In International Law (OUP, 2004), 155.

225 Århén (n 5), 139.

${ }^{226}$ CBD, principles of the ecosystem approach (n 79), Operational Guidance 2, para. 9; CBD refinement and elaboration of the ecosystem approach (n 79), para 12.5 .

227 Saramaka (Merits), para. 144; Endorois, paras. 235 and 249; and Kaliña and Lokono, paras 35-36.

${ }^{228}$ Saramaka (Merits), paras. 138-140; Kaliña and Lokono, para. 227; Endorois, paras. 298-299 and 295. J Pasqualucci, 'International Indigenous Land Rights: A Critique of the Jurisprudence of the Inter-American Court of Human Rights in Light of the United Nations Declaration on the Rights of Indigenous Peoples' (2009) 27 Wis. Int'l L.J. 51, 92.

${ }^{229}$ Gomez (n 10), 147-148.
} 
supportive interpretation may serve to clarify that fair and equitable benefit-sharing differs from reparations from a legal perspective, despite any overlap in practice in supporting the realization of communities' worldviews. It also points to practical difficulties in implementation.

At present, there has not been a jurisprudential clarification of the distinction between benefitsharing and compensation. The Inter-American Court explained the emergence of benefit-sharing as "inherent to the right of compensation" 230 for the "deprivation of the regular use of the enjoyment" of traditionally owned natural resources. ${ }^{231}$ The African Commission adopted the same reasoning. ${ }^{232}$ Former UN Special Rapporteur Anaya stated that the duty to share benefits is "independent of compensation measures," although it "responds in part to the concept of fair compensation for deprivation or limitation of the rights of the communities concerned, in particular their right of communal ownership of lands, territories and natural resources." ${ }^{233}$ The point was further blurred in a subsequent report. Anaya noted that "direct financial benefits - beyond incidental benefits like jobs or corporate charity - should accrue to indigenous peoples because of the compensation that is due to them for allowing access to their territories, for giving up alternatives for the future development of their territories, for suffering any adverse effects," as well as for the "significant social capital they contribute under the totality of historical and contemporary circumstances." 234 As discussed above, these elements are unlikely to be captured in impact assessments, but could be more systematically addressed in strategic environmental assessments, as recommended above. ${ }^{235}$

The practice of the Inter-American Court also points to some overlap in terms of aims of compensation and benefit-sharing. Reparations for material and immaterial damage (with the former including environmental damage affecting indigenous peoples' subsistence and spiritual connection with their territory) ${ }^{236}$ may take the form of community development funds (as a form of collective

\footnotetext{
${ }^{230}$ Inter-American Convention on Human Rights, art 21(2).

${ }^{231}$ Saramaka (Merits), paras. 13 and 140; see also paras. 143, 153, 156 making reference to reasonable share of benefits.

232 Endorois, para. 295.

${ }^{233}$ Special Rapporteur Anaya, A/HRC/15/37 (n 29), paras. 67, 89 and 91; and A/HRC/24/41 (n 121), para. 76.

${ }^{234}$ Special Rapporteur Anaya, A/HRC/24/41 (n 121), para. 76.

235 Section 2.3.

${ }^{236}$ Orellana (n 145), 845 and 847.
} 
reparation) with a view to contributing to enhancing the protection and development of indigenous peoples' cultural identity, and guaranteeing the control of their territories. These funds are further expected to contribute to indigenous peoples' development according to their life plans and to their present and future needs or enhancing the social and economic condition of the community, including in terms of increasing the productivity of natural resources or restoring degraded ecosystems. ${ }^{237}$ Community development funds can also be a form of benefit-sharing. Nevertheless, Anaya seems to suggest that benefit-sharing may make up for broader, historical inequities that have determined the situation in which the specific material and immaterial damage has arisen. ${ }^{238}$ These observations may support an argument whereby benefit-sharing is understood as a proactive tool for the full realization of human rights connected to natural resources in light of communities' worldviews. Benefit-sharing can thus be arguably distinguished from compensation that is expected to make up for lost control over resources and income-generation opportunities. ${ }^{239}$ Benefit-sharing combines instead new opportunities of income generation and continued, or possibly enhanced, control over the use of the lands and resources affected by the development, ${ }^{240}$ in line with the above-outlined argument about support- and control-benefits. ${ }^{241}$

Another argument discussed in the Inter-American context can, notwithstanding a certain teleological overlap, ${ }^{242}$ provide a stepping stone for distinguishing compensation from benefitsharing. As the Inter-American Court asserted, the creation of a community development fund as

\footnotetext{
${ }^{237}$ Saramaka (Merits), paras. 201-202; Garífuna de Punta Piedra, paras. 316 and 333; Kaliña and Lokono, para. 272; IACtHR, Comunidad Garifuna Triunfo de la Cruz y Sus Miembros vs Honduras (Merits, Reparations and Costs), 8 October 2015, para. 296 and concurrent opinion of Judge Humberto Antonio Sierra Porto, para. 26. Note also the inclusion of benefit-sharing among forms of compensation in T Ankowiak, 'A Dark Side of Virtue: The Inter-American Court and Reparations for Indigenous Peoples' (2014) 25 Duke J. Comp. \& Int'l L. 1, 5.

${ }^{238}$ Special Rapporteur Anaya, A/HRC/24/41 (n 121), para. 76. Other bodies have not elaborated on the point: UNPFII (n 57), para. 27 (2013); Ecuador, ILO Doc. GB.282/14/2, para. 44(c)(3) (2001), and Bolivia, ILO Doc. GB.272/8/1:GB.274/16/7, para. 40 (1999).

${ }^{239}$ F Lenzerini, 'Reparations for Indigenous Peoples in International and Comparative Law: An Introduction' in Lenzerini (n 6) 3, 13-14. See also D Shelton, 'Reparations for Indigenous Peoples: The Present Value of Past Wrongs' in Lenzerini (n 6) 47, 60-61 and 66-69.

${ }^{240}$ Morgera (n 20), on the basis of Special Rapporteur Anaya, A/HRC/21/47 (n 21), paras. 68,74 and 76 and A/HRC/24/41 (n 121), para. 75.

${ }^{241}$ See section 2.2 above.

${ }^{242}$ See discussion on potential for reparations to aim at restorative justice and be forward-looking (and controversy around that notion) in Shelton (n 239), 72. See also Gomez (n 10), 147-148.
} 
compensation for material and immaterial damage is "additional to any other benefit present and future that communities are owed in relation to the general obligations of development of the State." 243 The Inter-American Court contrasted the secondary obligation of compensation, deriving from and commensurate to a violation of human rights, and the State's general obligations to realise indigenous peoples' right to the protection of the environment, the productivity of their territories and natural resources, ${ }^{244}$ and the enhancement of their quality of life. ${ }^{245}$ It is argued here that a similar distinction can apply to fair and equitable benefit-sharing as an inherent component of certain human rights: it is therefore part of a general and permanent obligation to protect and realise human rights connected to natural resources, that is independent of any violation of these rights and related compensation. ${ }^{246}$ Distinguishing benefit-sharing from compensation for material and immaterial damage $^{247}$ could thus decouple the former from the need to establish a causal nexus between an ascertained human rights violation, and a damage arising from the violation. ${ }^{248}$ This is particularly significant in light of the Inter-American Court's tendency to mitigate a State's financial burden in cases concerning communities, and its inadequate account of the difficulties of indigenous and tribal peoples to document environmental and cultural harm. ${ }^{249}$

Admittedly, the Court's remarks about "any other benefit present and future that communities are owed in relation to the general obligations of development of the State" may also refer to the State's obligations to realise the generally applicable civil and political, as well as economic, social and cultural rights of the population at large. This raises the issue of distinguishing benefit-sharing as

\footnotetext{
243 Garifuna Triunfo de la Cruz, para. 295; Garifuna de Punta Piedra, 332; Kaliña and Lokono, para. 295.

${ }^{244}$ In light of UNDRIP art 29(1): Garifuna de Punta Piedra, para. 333. Note, however, that the distinction between primary duties to fulfil general human rights from the secondary duty to provide reparation for violations of indigenous and tribal peoples' rights connected to natural resources remains to be clearly drawn: Gomez (n 10), 149.

${ }^{245}$ Such as ILO Convention 169, art 2.2.b: "promoting the full realization of the social, economic and cultural rights of these peoples with respect for their social and cultural identity, their customs and traditions and their institutions": Garifuna Triunfo de la Cruz, concurrent opinion of Judge Humberto Antonio Sierra Porto, para. 30-31.

${ }^{246}$ This interpretation appears supported by ILA (n 22, 42-43) with regard to UNDRIP art 32(2) and opportunities offered by indigenous lands to develop economic projects.

${ }^{247}$ Orellana (n 145), 845 and 847.

${ }^{248}$ And generally "restricts damage to provable, proximate losses to avoid excessive recovery," although it includes some flexibility in the name of proportionality and equity: Shelton (n 239) 60.

${ }^{249}$ Ankowiak (n 237) 5.
} 
an inherent component of human rights connected to natural resources, from the State's general duty to fulfil general human rights, which is hard to do in practice. In effect, it has been empirically observed that "communities are losing out on any additional benefits that may otherwise have been provided through benefit-sharing" 250 when the State has not delivered basic services to these communities. To provide an example, when a community consented to laying fibre optics in its traditional territory, it obtained as benefit-sharing the overdue issuance of IDs for its members, and free internet for the community school, but not for all community households. This example serves to reiterate the importance of thinking strategically about the interface of benefit-sharing with assessments and FPIC, as prior assessments could scope more broadly and proactively possible benefits in accordance with communities' worldviews. It also reinforces the argument made above about the importance of strategic environmental assessments to factor in historical and systemic issues that affect the understanding of benefits beyond decision-making at the individual project level.

\section{The legal status of benefit-sharing at the intersection of international biodiversity and human rights law}

At present, the emergence of fair and equitable benefit-sharing obligations in relation to the rights of indigenous and tribal peoples over natural resources, and the rights of other communities that are connected to natural resources, is largely supported by authoritative interpretations, rather than unequivocal treaty provisions. In addition, the evolutionary interpretation of international human rights law is not yet firmly based on systematic and coherent reliance on international biodiversity law. Even after the clarifications provided by the UN Framework Principles on Human Rights and the Environment, there remains significant scope for scholars to assess the level of State support, particularly where

\footnotetext{
${ }^{250}$ Wynberg \& Hauck (n 30), 158.
} 
key interpretative questions may not have been clearly and coherently addressed in universal, regional and domestic processes. Nevertheless, as Special Rapporteur Knox has argued, at the very least growing "coherence in the interpretation by binding human rights tribunals and authoritative human rights bodies" crystallises "best practices" that serve to "facilitate the implementation" of existing international obligations, ${ }^{251}$ providing "strong evidence of the converging trends towards greater uniformity and certainty in the understanding. ${ }^{, 252}$ On the side of international biodiversity law, the legal nature of relevant CBD provisions has been openly contested. ${ }^{253}$ In addition, the qualifications in the CBD guidance represent disagreement among CBD Parties as to whether certain interpretations are reflecting existing or emerging international law, based also on the fact that each individual Party to the CBD may not have formally accepted the same underlying international human rights norms. At the very least, guidance adopted as consensus decisions under the CBD should also be considered a crystallization of "best practices" that serve to "facilitate the implementation" of existing international obligations. It thus becomes increasingly difficult for a State to defend an approach that goes against an internationally recognised best practice, particularly when it has intensely participated in intergovernmental negotiations and eventually agreed upon the formulation of such best practices. ${ }^{254}$ Against this backdrop, the above-outlined mutually supportive interpretation of international human rights and biodiversity law may support an original reflection on the legal status of an international benefit-sharing obligation at the intersection of these two areas. This section will thus shed new light on this matter by reflecting on the legal bases for benefit-sharing in international human rights law and the interplay of benefit-sharing with consent and impact assessment.

251. Knox (n 2), paras 7-8.

252. To use the terminology employed by Knox (n 2), paras 7-9. See generally, C Buckley, A Donald and P Leach (eds), Towards Convergence in International Human Rights Law: Approaches of Regional and International Systems (Brill, 2016).

${ }^{253}$ See generally S Harrop and D Pritchard, 'A Hard Instrument Goes Soft: The Implications of the Convention on Biological Diversity's Current Trajectory’ (2011) 21 Global Envt'l Change 474; and Construction of a Road in Costa Rica Along the San Juan River (Nicaragua v. Costa Rica), ICJ 16 December 2015, (Road Case) para. 164, which focused on CBD art 14 on environmental assessments that has provided the basis for interpretative developments related to benefit-sharing in international biodiversity and human rights law, as discussed above.

${ }^{254}$ E Morgera, 'Dawn of a New Day? The Evolving Relationship between the Convention on Biological Diversity and International Human Rights Law’ (2018) 54 Wake Forest Law Review. 
Benefit-sharing obligations have been associated with a variety of inter-linked human rights, such as indigenous peoples' right to freely dispose of their natural resources, ${ }^{255}$ which is connected with their right to freely determine and enjoy their own social, cultural and economic development, as well as the right to enjoy their way of life that is closely associated with the use of resources ${ }^{256}$ upon which their cultural identity depends. ${ }^{257}$ The Inter-American Court substantiated these rights on the basis of its notoriously evolutive understanding of the right to property, ${ }^{258}$ in connection with the right to self-determination under common Article 1 of the two Covenants, ${ }^{259}$ and the right to culture under Article 27 of the International Covenant on Civil and Political Rights. ${ }^{260}$ For its part, the African Commission focused, in addressing benefit-sharing, on the right to development, which is explicitly provided for under the African Charter, but it argued that its interpretation also built on the InterAmerican Court and CERD jurisprudence. ${ }^{261}$ In effect, successive Inter-American Court's cases in the line of the Saramaka jurisprudence, have elaborated upon the notion of development as part of the need to ensure the physical and cultural survival of indigenous peoples by protecting their right to natural resources. ${ }^{262}$ In addition, the Inter-American Court equated explicit mechanisms that guarantee effective benefit-sharing with political rights, relying on the CBD obligation on environmental impact assessments. ${ }^{263}$ Overall, benefit-sharing has emerged as part of an evolving

\footnotetext{
${ }^{255}$ Comunidad Garifuna Triunfo de la Cruz, para. 167. This interpretation is now enshrined in American Declaration on the Rights of Indigenous Peoples (2016), Art XXIX. See also Endorois, paras. 120-124.

${ }^{256}$ Saramaka (Merits), paras. 93-95 on the basis also of Inter-American Convention, art 29(b). Reiterated in Kaliña and Lokono, para. 124. For a succinct discussion of previous case law, see e.g. Århén (n 5), 93.

${ }^{257}$ Kaliña and Lokono, paras. 181 and 193.

${ }^{258}$ Art 21 of American Convention on Human Rights (adopted 22 November 1969, entered into force 18 July 1978) 1144 UNTS 123. Saramaka (Merits), paras. 115 and 120; based on IACtHR, Case of the Mayagna (Sumo) Awas Tingni Community v Nicaragua (Judgment) (31 August 2001).

${ }^{259}$ International Covenant on Civil and Political Rights (ICCPR), 26 December 1966, 999 UNTS 171. See generally J Anaya, Indigenous Peoples in International Law (OUP, 2004), 104-106 and 129-131; and Århén (n 5).

${ }^{260}$ HRC, Lubicon Lake Band v Canada, Comm No 167/1984 (26 March 1990) UN Doc. Supp No 40 (A/45/40) and Ángela Poma Poma v Peru, Comm No 1457/2006 (27 March 2009) UN Doc. CCPR/C/95/D/1457/2006. This approach has been confirmed by the ICJ, Navigational and Related Rights (Nicaragua v Costa Rica) (Judgment) 13 July 2009 , [2009] ICJ Reports 213.

${ }^{261}$ Endorois, paras. 294 and 296. As to the former, the African Commission presumably referred to Saramaka (Merits), paras, 93-95, and Saramaka (Interpretation), para. 46. CERD, General Recommendation No. 23: Indigenous Peoples, UN Doc. A/52/18, annex V, para. 4 (1997); CERD, Concluding Observations on Ecuador, UN Doc. A/58/18, para. 62 (2003).

262 Comunidad Garifuna Triunfo de la Cruz, para. 102; Comunidad Garífuna de Punta Piedra, para. 167.

${ }^{263}$ Kaliña and Lokono, para. 197, relying on CBD art 14 and Rio Principle 17.
} 
understanding of "overlapping and multi-layered international human rights grounded on the centrality of natural resources for the identity and recognition of indigenous and tribal peoples." 264

As Special Rapporteur Anaya indicated, benefit-sharing is thus not a new human right, but it is rather connected to existing rights, ${ }^{265}$ in line with the argument that benefit-sharing is implicit in indigenous peoples' human rights to natural resources under UNDRIP mentioned above. This view pre-empts the need to prove the emergence of new international obligations than those that have already been identified under several, global and regional, human rights treaties. The idea that benefitsharing is an inherent component of existing human rights connected to natural resources, furthermore, permits to move away from considering benefit-sharing as a mere safeguard, only coming into play for the protection of rights (in other words, a defensive tool). Instead, it supports the view that benefit-sharing has also the potential to support the realization of these rights (serving as a proactive tool).

In addition to specific treaty bases for specific human rights, the interplay between benefitsharing obligations and FPIC can underpin also another argument about the status of the former in international law. Benefit-sharing could be seen as part of the general international principle of effective consultation. ${ }^{266}$ As such, it would affect the exercise of States' discretionary powers in relation to the development, interpretation, and application of international law even in the absence of an applicable treaty basis. ${ }^{267}$ This argument may be well suited for the international benefit-sharing obligations towards local (non-indigenous) communities ${ }^{268}$ whose human rights to participation, culture

\footnotetext{
264 G Pentassuglia, 'Ethnocultural Diversity and Human Rights: Legal Categories, Claims, and the Hybridity of Group Protection' (2015) 6 Yb Polar L 251, 293, 276-277, 294 and 317; IACtHR, Case of the Saramaka People v. Suriname, Judgment (Interpretation of the Judgment on Preliminary Objections, Merits, Reparations and Costs), 12 August 2008, paras. 25-27; Endorois para 151; Ogiek, para 191.

${ }^{265}$ At the beginning of his mandate, UN Special Rapporteur on Indigenous Peoples' Rights, James Anaya, hypothesized that benefit-sharing could be a right in itself: A/HRC/15/37 (n 29), paras. 67 and 76-78, but his more definite argument focused on benefit-sharing as a safeguard ancillary to existing rights: A/HRC/21/47 (n 22), paras. 52 and 62.

${ }^{266}$ Comunidad Garifuna de Punta Piedra, para. 222; Pentassuglia (n 18), 176 sees benefit-sharing as "expanding on the principle of effective participation".

${ }^{267}$ A Boyle \& C Chinkin, The Making of International Law (Oxford University Press, 2007), 222-225.

${ }^{268}$ UN Framework Principle 15 (n 2); CBD, arts 8(j) and 10(c); Food and Agricultural Organization of the United Nations (FAO), Voluntary Guidelines on the Responsible Governance of Tenure of Land, Fisheries and Forests in the Context of National Food Security (VGGT) (2012), art 8.6; and FAO, Voluntary Guidelines for Securing Sustainable Small-scale Fisheries in the Context of Food Security and Poverty Eradication (2013), para 5.1.
} 
and subsistence are intrinsically connected to natural resources, ${ }^{269}$ but whose status in international law remains unclear. ${ }^{270}$

In addition, in understanding the common thread among multiple rights and multiple rightholders, the link between benefit-sharing and non-discrimination has been emphasised by former UN Special Rapporteur on Human Rights and the Environment John Knox. He considered benefitsharing as an "additional measure to protect those who are most vulnerable to, or at particular risk from, environmental harm," with a view to complementing effective measures against the underlying conditions that cause or help to perpetuate discrimination. This is the case of measures (such as mining and logging concessions) that have disproportionately severe effects on communities that rely on ecosystems, or that are likely to cause environmental harm reinforcing historical or persistent prejudice against groups of individuals. ${ }^{271}$ Accordingly, it would be discriminatory to take as criteria for traditional occupation or use a certain amount of continuity or patterns of sufficiently intense use on the basis of the larger society's understanding. Rather, benefit-sharing obligations arise also from the use of resources that are possessed without title 272 or for which communities unwillingly lost $\operatorname{possession}^{273}$ and are therefore shared with majority population, as long as there is continuity in indigenous peoples' terms of "values" and "shared mentality" related to these resources. ${ }^{274}$ Focusing on non-discrimination as the cross-cutting legal basis of benefit-sharing under international human rights law has the potential for a two-fold clarification. First, it reveals the strategic advantage of relying on, among available human rights treaty bases, the Convention on the Elimination of Racial

\footnotetext{
${ }^{269}$ UN Framework Principle 15 (n 2), para 41(d) and (g) and 48; O De Schutter, 'The Emerging Human Right to Land' (2010) 12 Int'l Community L Rev 303, 319 and 324-325; Pentassuglia (n 38), 157; and C Doyle \& J Gilbert, 'Indigenous Peoples and Globalization: From "Development Aggression" to "Self-Determined Development"” (2008/9) 7 Eur. Y.B. Minority Issues 219.

${ }^{270}$ Note, eg, votes against and abstentions concerning the adoption of the Declaration on the Rights of Peasants and Other People Working in Rural Areas, UN Doc. A/HRC/39/12 (2018) at the Human Rights Council; CBD Decisions X/43 (2010), para 21 and XI/14 (2012), para 19.

${ }^{271}$ UN Framework Principles (n 2), para 9.

${ }^{272}$ Endorois, paras. 204-207.

273 Endorois, para. 209.

${ }^{274}$ Århén (n 5), 179. Ogiek, para 185. Note that the concept of "tradition" is contested in anthropological studies: eg R Ellen et al (eds.), Indigenous Environmental Knowledge and Its Transformation: Critical Anthropological Perspectives (Harwood Academics, 2000).
} 
Discrimination, which is the most widely applicable (179 Parties) in those countries that are not party to the Inter-American or African regional treaties and that have expressed limitations to their implementation of UNDRIP. CERD has systematically relied on the findings of the Inter-American Court on benefit-sharing, ${ }^{275}$ arguably indicating that it is an inherent component of indigenous peoples' rights to natural resources and that it differs from damages. ${ }^{276}$ Second, the connection between benefit-sharing and non-discrimination could support the argument that an international benefit-sharing obligation is part and parcel of the customary international law prohibition of discrimination on racial grounds, ${ }^{277}$ which binds States even in the absence of applicable treaty bases and is considered ius cogens, thereby prevailing over other treaty provisions.

Another common normative thread could also be explored - human dignity. This concept was only mentioned once by the Inter-American Court, ${ }^{278}$ but scholarship on human dignity and the environment arguably provides a broader, coherent framework for understanding benefit-sharing in the context of overlapping human rights of indigenous peoples and local communities. Human dignity encompasses the interplay of self-determination (agency and autonomy in determining the course of one's life), subsistence (material dignity as the minimum conditions for physical and cultural existence), non-discrimination (the right to be acknowledged as equals against the background of historically entrenched and pervasive discrimination) and political participation (the opportunity for rightholders to preserve their identity and culture as part of broader society). ${ }^{279}$ Human dignity is seen as a collective right (to be exercised as part of one's community and one's society) and as a collective obligation. From the latter perspective, it requires, on the one hand, not just protection, but also

\footnotetext{
${ }^{275} \operatorname{Eg}$ CERD (n 51).

${ }^{276}$ J Gilbert, "CERD's Contribution to the Development of the Rights of Indigenous Peoples under International Law" in D Keane and A Waughray (eds), Fifty Years of the International Convention on the Elimination of All Forms of Racial Discrimination: A Living Instrument (Manchester University Press, 2017) on the basis of CERD/C/63/CO/2 and $\mathrm{CERD} / \mathrm{C} / \mathrm{PER} / \mathrm{CO} / 18-21$.

${ }^{277}$ IACtHR, Xákmok Kásek Indigenous Community v. Paraguay, Judgment (24 August 2010), Sect. 3.1 and n. 37 ; see Fodella (n 24), 358.

${ }^{278}$ Kaliña and Lokono, paras. 181 and 193 referring to the "right to a dignified life ... connected with natural resources on ... traditional territories.".

${ }^{279}$ E Daly, Dignity Rights: Courts, Constitutions and the Worth of the Human Person (University of Pennsylvania Press, 2013) 5, 40, 59-60 and 119.
} 
support from the State, which can be related to the various forms of non-monetary benefits identified under the CBD. On the other hand, a collective obligation also entails efforts from all to respect the dignity of every other, in ways that are contextual to the history and present challenges of a society. ${ }^{280}$

Overall, the relevance of benefit-sharing for non-discrimination and human dignity of indigenous peoples and other communities remains to be studied more fully. There is significant scope for scholars to further explore and advocates to test the proposed mutually supportive interpretation outlined above.

\section{Business responsibility to respect human rights connected to natural resources}

In light of the widespread recognition that private companies have a responsibility to respect internationally recognised human rights over and above what is required of them by national laws, and independently of States' abilities and willingness to fulfil their human rights obligations, ${ }^{281}$ this section will discuss cross-fertilization between international human rights and biodiversity law on benefit-sharing with regard to business responsibility to respect the human rights of indigenous peoples. This cross-fertilization has provided more specific international benchmarks for: i) the private sector to guide its own conduct so as to prevent conflicts over natural resources with communities; ii) for community advocates to hold the private sector accountable for alleged substandard environmental and human rights practices in the natural resource sector; and iii) for

\footnotetext{
${ }^{280}$ Ibid, 119-121.

${ }^{281}$ Special Representative Ruggie, "Guiding Principles on Business and Human Rights to implement the UN Protect, Respect and Remedy Framework”, UN Doc. A/HRC/17/31 (2011), adopted by the Human Rights Council (Res 17/4 (2011)) and "Protect, Respect and Remedy: A Framework for Business and Human Rights", UN Doc. A/HRC/8/35 (2008), which the Human Rights Council recognized the need to operationalize (Res 8/7 (2008), para. 2) and the Expert Mechanism (n 5), para 21, considered "authoritative global standard for addressing business-related human rights challenges." Note, however, that the Human Rights Council established in 2014 a process to elaborate an international legally binding instrument on transnational corporations and other business enterprises and human rights: HRC Res 26/9 (June 25, 2014). See also ILA, Second Report of the Study Group on Due Diligence in International Law (July 2016) 27-39.
} 
international monitoring mechanisms to provide independent fact-finding and mediation services. ${ }^{282}$ This section will also analyse the relevance of the interplay among fair and equitable benefit-sharing, FPIC, impact assessment and compensation, for business due diligence. In addition, as States retain ultimate responsibility to ensure compliance with international human rights law by private companies, ${ }^{283}$ relevant international standards also serve to clarify States' obligations to develop and enforce legislation, and provide access to justice, to ensure that businesses exercise due diligence. ${ }^{284}$ This section will thus complement the previous discussion of State obligations with additional considerations concerning the oversight of contractual practices related to benefit-sharing, as well as the negotiation and enforcement of State-investors agreements.

\subsection{International standards for business responsibility}

A plethora of international legal materials point to the applicability of socio-cultural and environmental impact assessment, FPIC and benefit-sharing to business enterprises in the natural resource sector. ${ }^{285}$ In particular, UN Special Rapporteur Anaya and the UN Expert Mechanism on Indigenous Peoples' Rights have relied on CBD materials ${ }^{286}$ to argue that business responsibility in

\footnotetext{
${ }^{282}$ E Morgera, Corporate Accountability in International Environmental Law (Oxford University Press, 2009).

${ }^{283}$ Special Rapporteur Anaya, Extractive industries operating within or near indigenous territories, UN Doc. A/HRC/18/35, para. 63 (2011); UN Expert Mechanism (n 5), para. 8; and Shelton (n 74), 553.

${ }^{284}$ Draft General Comment on State Obligations under the ICESCR in the context of Business Activities, UN Doc. E/C.12/60/R.1, paras. 17-21 (2016).

${ }^{285}$ Albeit to different extents: S Seck, 'Indigenous Rights, Environmental Rights, or Stakeholder Engagement? Comparing IFC and OECD Approaches to the Implementation of the Business Responsibility to Respect Human Rights' (2016)12 Mcgill J. Int'l Sustainable Dev. L. \& Prac 51. See contra C Lewis, 'Indigenous Peoples and the Corporate Responsibility to Respect Human Rights' in Lennox and Short (n 17) 201, 215.

${ }^{286}$ E Morgera, 'Benefit-sharing as a Bridge between the Environmental and Human Rights Accountability of Multinational Corporations' in Boer (n 145) 37. CBD decisions are routinely addressed directly also to private operators, thereby providing an intergovernmentally adopted source of more specific corporate accountability standards. E.g., Addis Ababa Guidelines (n 56), para. 1; Guidelines on Biodiversity and Tourism (n 88), para. 2, and Tkarihwaié:ri Code (n 114), section 6/3. The Akwé: Kon Voluntary Guidelines, albeit directed to parties and governments (n 52), para. 1), are expected to provide a collaborative framework for governments, indigenous and local communities, decision makers and managers of developments (ibid, para. 3).
} 
the extractives sector ${ }^{287}$ includes benefit-sharing ${ }^{288}$ and depends on companies facilitating indigenous peoples' full access to information about potential financial benefits, even when this information is considered proprietary (in which case, it should be shared on a confidential basis). ${ }^{289}$ In addition, CBD guidelines call for adequate and balanced information from a variety of sources to be made available in accessible terms and indigenous or local languages, to ensure that all parties to a benefitsharing agreement have the same understanding of the information and terms provided. ${ }^{290}$ Anaya added that in exercising due diligence, companies must identify, prior to commencing activities, all matters related to indigenous peoples' rights and recognise their social and political structures, as well as their possession and use of land and natural resources. ${ }^{291}$

Similarly to States' benefit-sharing obligations, Anaya also emphasised that companies should consider benefit-sharing as a tool to create genuinely equal partnerships with indigenous peoples. ${ }^{292}$ He therefore criticised common corporate practices envisaging benefit-sharing as compensation, as a charitable award or as a favour granted to secure social support for a project. ${ }^{293}$ Anaya instead envisaged that, if indigenous peoples themselves do not wish or are unable to initiate resource extraction, benefit-sharing entitles them to participate in project decision-making and share in their profits through an agreement with outside companies (for instance, through a minority ownership interest in the extractive operations). ${ }^{294}$ This points to the need for both enhanced participation opportunities and income generation for indigenous peoples - the procedural and substantive side of benefit-sharing, as discussed above. Accordingly, this would also imply moving away from an exclusive focus on damage prevention to a proactive and collaborative identification of benefit-

\footnotetext{
${ }^{287}$ See generally Special Rapporteur Anaya, A/HRC/21/47 (n 21), and A/HRC/24/41 (n 121), para. 62; and UN Expert Mechanism (n 5) and (n 198), paras. 8-29.

${ }^{288}$ Special Rapporteur Anaya, A/HRC/15/37 (n 29), paras. 46 and 79.

${ }^{289}$ Special Rapporteur Anaya, A/HRC/24/41 (n 121), paras. 62, 66, and 72.

${ }^{290}$ CBD, Mo'otz Kuxtal Guidelines (n 75), para. 17(c)(iii).

${ }^{291}$ Special Rapporteur Anaya, A/HRC/15/37 (n 29), para. 46.

${ }^{292}$ Special Rapporteur Anaya, Report on the rights of indigenous peoples, (2011) UN Doc. A/HRC/66/288, para. 102 and $\mathrm{A} / \mathrm{HRC} / 21 / 47$ (n 21), paras. 68, 74 and 76.

293 Special Rapporteur Anaya, A/HRC/15/37 (n 29), paras 79, 89 and 91.

294 Special Rapporteur Anaya, A/HRC/24/41 (n 121), para. 75.
} 
sharing opportunities according to indigenous peoples' worldviews. ${ }^{295}$

In 2017 UN Special Rapporteur Knox clarified that similar standards to those spelt out for business and other non-State actors in extractives are also relevant for private operators involved in conservation. ${ }^{296}$ The intergovernmental consensus achieved under the CBD on indigenous and community conserved areas was considered particularly instructive in this connection, ${ }^{297}$ starting from the need to recognise, respect and support community-based approaches to conservation and the integration of communities in governance and management arrangements. ${ }^{298}$

Experience with business-community benefit-sharing models, however, has been far from clearly beneficial towards indigenous peoples, as they have involved unfair pricing and indebtedness. ${ }^{299}$ Several other concerns arise with regard to the use of contractual tools for incorporating benefit-sharing agreements, which generally provide the form for "mutually agreed" benefits, as referred by both human rights bodies and CBD Parties for a contextual application of benefit-sharing. ${ }^{300}$ Contractual negotiations may in principle function as a dialogic partnership-building process between private companies and communities. But leaving a contextual determination of fairness and equity to contractual freedom has raised concerns in the face of the well-documented, unequal negotiating powers, as well as information and capacity asymmetries. ${ }^{301}$ These concerns are compounded by objective difficulties in reconciling communities' customary law within dominant legal systems, ${ }^{302}$ including in connection with dispute resolution.

\footnotetext{
${ }^{295}$ UN Expert Mechanism (n 5), para. 39(h) and implicitly UK National Contact Point, Final Statement on the Complaint from Survival International against Vedanta Resources plc, at http://www.berr.gov.uk/files/file53117.doc, para. 73 (2009).

${ }^{296}$ Special Rapporteur on Human Rights and the Environment John Knox, Report on biodiversity and human rights, (2017) UN Doc. A/HRC/34/49, para 72.

${ }^{297}$ H Jonas, 'Indigenous Peoples' and Community Conserved Territories and Areas (ICCAs): Evolution in International Biodiversity Law' in Morgera and Razzaque (n 79) 145.

${ }^{298}$ CBD Decisions X/31/B (2010) para 31, XII/19 (2014) para 4(f) and X/33 (2010) para 8(i) in relation to climate change (which area addressed to "other/relevant organizations"); and XII/5 (2014) para 11 (which is addressed to "relevant stakeholders.")

${ }^{299}$ Cotula and Tienhaara (n 203), 293.

${ }^{300}$ Kaliña and Lokono, paras. 227-229 and 159. For a discussion, Lucas (n 110).

${ }^{301}$ Morgera et al (n 77), 7.

${ }^{302}$ For a reflection on the challenges of legal pluralism in the context of benefit-sharing from bioprospecting, see $\mathrm{S}$ Vermeylen, 'The Nagoya Protocol and Customary Law: The Paradox of Narratives in the Law' (2013) 9 L. Envt \& Dev. J. 185.
} 
In principle, benefit-sharing contracts may provide an opportunity to "co-author" the terms of cooperation with third parties. ${ }^{303}$ Contracts may incorporate community worldviews as principles of interpretation, and/or as elements determining the fairness and equity in benefit-sharing. ${ }^{304}$ They may also incorporate reference to international human rights standards ${ }^{305}$ to substantiate contractual obligations to respect community worldviews. Such an incorporation of different worldviews in contractual arrangements faces several practical challenges deriving from the limited opportunities for full and effective community engagement in contractual negotiations and likely clashing with the developer's commercial demands for expediency and cost-effectiveness. ${ }^{306}$ A further layer of complexity arises from confidentiality clauses in benefit-sharing agreements, which limits crosscommunity communication of lessons learnt in negotiating benefit-sharing. ${ }^{307}$ These fundamental challenges add to significant technical difficulties in accounting, calculating benefits and ensuring environmental sustainability, that require significant administrative capacity. For these reasons, Anaya recommended that business' benefit-sharing contribute to "genuinely strengthen the capacity of indigenous peoples to establish and pursue their own development priorities and that help indigenous peoples to make their own decision-making mechanisms and institutions more effective". ${ }^{308}$ Support-benefits should thus also be provided by private companies, with a view to enabling communities to play increasingly more significant roles in development projects. ${ }^{309}$

Some evidence has been accrued that business-community benefit-sharing arrangements can avoid paternalistic approaches and genuinely serve communities' vision for their economic

\footnotetext{
${ }^{303}$ Craik et al (n 173), 386.

${ }^{304}$ K Carpenter \& A Riley, 'Indigenous Peoples and the Jurisgenerative Moment in Human Rights' (2014) 102 Cal. L. Rev. 173.

${ }^{305}$ Cotula and Tienhaara (n 203), 302.

${ }^{306}$ Craik et al (n 173), 384.

${ }^{307}$ K Caine \& N Krogman, 'Powerful or Just Plain Power-Full? A Power Analysis of Impact and Benefit Agreements in Canada's North' 23 Org. \& Envt 76 (2010). See also M Langton, 'The Resource Curse Compared: Australian Aboriginal Participation in the Resource Extraction Industry and Distribution of Impacts' in M Langton \& J Longbottom eds., Community Futures, Legal Architecture: Foundations for Indigenous Peoples in the Global Mining Boom (Routledge, 2012) 23, 29 and 38.

308 Special Rapporteur Anaya, A/66/288 (n 292), para. 102

${ }^{309}$ Cotula and Tienhaara (n 203), 293.
} 
participation and enterprise development, rather than mere accumulation and distribution of profit. ${ }^{310}$ This can be the case of genuine agreement on benefits involving access to and management of natural resources, heritage management, and decommissioning, which should be clearly additional to the protection of the right to engage in traditional activities ${ }^{311}$ - the control-benefits discussed above. ${ }^{312}$

\subsection{State obligations in the context of private contracts and investment agreements}

A recent analysis in the Canadian context has underscored that despite their private law nature, business-community benefit-sharing contracts are meant to secure public benefits, as an indirect means for the governments to comply with international and constitutional obligations towards indigenous peoples. ${ }^{313}$ From the government perspective, these contracts incorporate the findings of impact assessments, as well as provide for follow-up and monitoring obligations mandated by national law. ${ }^{314}$ With regard to the role of States, CBD guidelines have focused on the need for practical cooperation between the government and communities to support negotiations with private companies and implementation of private contracts, ${ }^{315}$ by setting standard contractual clauses, establishing direct payments, or creating trust funds. ${ }^{316}$ Financial support or capacity-building to address challenges in contractual arrangements, however, are rarely provided by States. ${ }^{317}$ On the other hand, indigenous groups may have recourse to confidentiality to prevent governments from using knowledge of agreed benefits as a justification to reduce their entitlements. ${ }^{318}$

\footnotetext{
310 See generally M Langton, 'Introduction' in Langton \& Longbottom (n 307) 1.

${ }^{311}$ K Doohan et al., 'From Paternalism to Partnership: The Good Neighbour Agreement and the Argyle Diamond Mine Indigenous Land Use Agreement in Western Australia' in Langton \& Longbottom (n 307) 232, 244-246.

312 See section 2.1 .2 above.

313 See generally Craik et al (n 173).

${ }^{314}$ Ibid, 383.

315 Akwé: Kon Guidelines (n 52), para. 40.

${ }^{316}$ CBD Secretariat, "How tasks 7, 10 and 12 could best contribute to work under the Convention and to the Nagoya Protocol”, (2012) UN Doc. UNEP/CBD/WG8J/8/4/Rev.2, para. 23. Community development funds were also referred to in Saramaka (Merits), para. 201 and ILO (n 31), 107-108.

${ }^{317}$ Craik et al (n 173), 385.

318 Ibid.
} 
Business enterprises themselves, in responding to a questionnaire circulated by Special Rapporteur Anaya, have lamented the lack of clear regulatory frameworks on benefit-sharing at the national level. ${ }^{319}$ Commentators have argued that States' obligations to develop domestic benefitsharing measures need to require companies to share benefits with all community members, rather than only those directly participating in joint ventures, through different stages of the project cycle. ${ }^{320}$ Furthermore, national legal frameworks need to determine the extent to which developers will be held responsible for monitoring project impacts, disseminating information and using it to inform periodic reviews of benefit-sharing agreements in light of international standards of best practice. ${ }^{321}$ As discussed above, the need for legal rules in relation to benefit-sharing is a dimension of State obligations that is often under-emphasised in international biodiversity law also with regard to effective regulation and control of private actors. Instead, domestic legislation is needed to ensure that benefit-sharing serves as a "limit to contractual autonomy," on the basis of international human rights law. ${ }^{322}$

With regard to the role of governments in ensuring the fairness of contractual arrangements, former UN Special Rapporteur Anaya underlined that "the State remains ultimately responsible for any inadequacy in the consultation or negotiation procedures and therefore should employ measures to oversee and evaluate the procedures and their outcomes, and especially to mitigate against power imbalances between the companies and the indigenous peoples with which they negotiate." 323 To this end, consultations carried out directly by private companies with indigenous peoples should be supervised by the State. ${ }^{324}$ States are also to verify that benefit-sharing agreements with extractive industries are crafted on the basis of full respect for indigenous peoples' rights. ${ }^{325}$

\footnotetext{
319 Special Rapporteur Anaya, A/HRC/18/35 (n 283), para. 49.

${ }^{320}$ C Filer, 'The Development Forum in Papua New Guinea: Evaluating Outcomes for Local Communities' in Langton and Longbottom (n 307) 145, 158.

321 Ibid.

${ }^{322}$ Francioni (n 111) 3, 23-24 and 27.

${ }^{323}$ Special Rapporteur Anaya, A/HRC/24/41 (n 121), para. 62.

324 Ibid.

${ }^{325}$ Ibid, paras. 88 and 92.
} 
On the ground, some evidence points to substantive positive impacts of government's participation in negotiations between communities and companies. ${ }^{326}$ But communities themselves may not wish to involve the government out of concern that the contract may become a source of external control (including on the distribution of benefits within the community). ${ }^{327}$ More generally, communities could find themselves in an adversarial relationship with the government, as different State entities may have a vested interest in the negotiations. One approach to address these concerns would be relying on national human rights ombudsman as semi-independent government entities that can mediate and facilitate negotiations between private companies and communities, including by signalling when proposals may be undermining existing human rights.

Even more complexity surrounds community negotiations with private operators that are foreign investors. These negotiations may be constrained by the terms of an investor-State contract, which may limit the types of benefits to be made available, such as local employment and local business opportunities. ${ }^{328}$ While there is still limited international guidance on this, certain roles for the State can be identified. States could include in their agreement with investors an obligation for the latter to conclude a benefit-sharing agreement with communities, determining goals and minimum parameters below which the investor-community agreement cannot go. ${ }^{329}$ This would allow the government to monitor and enforce possible violations of the investor-community benefit-sharing contract, including by sanctioning the violation of key terms of benefit-sharing contracts with the termination of State-investor agreements. ${ }^{330}$

Overall, the use of private and/or public instruments for encapsulating mutually agreed benefitsharing remains a matter for further study in international environmental, human rights and investment law. Much remains to be understood about the actual room for communities' worldviews

\footnotetext{
${ }^{326}$ Langton (n 307), 32.

${ }^{327}$ Craik et al (n 173), 385.

${ }^{328}$ Cotula and Tienhaara (n 203), 292.

${ }^{329}$ Albeit to the extent allowed by the State's bilateral investment treaties: ibid, 303 and 294.

${ }^{330}$ Ibid, 303 and 293.
} 
to be expressed, understood and realised within contractual, investment, and corporate legal tools and structures. ${ }^{331}$ More research is required on the necessary oversight of benefit-sharing agreements, including with regard to integrating in such scrutiny also indigenous procedural and substantive standards. $^{332}$

\section{Conclusions}

Fair and equitable benefit-sharing has gradually emerged as an inherent component of human rights connected to natural resources in its interplay with impact assessment and FPIC. This represents a growing area of cross-fertilization between international human rights and biodiversity law, even if the latter generally avoids human rights language. While such cross-fertilization is still incipient, this analysis has pointed to further opportunities for a fully-fledged mutually supportive interpretation of benefit-sharing. Human rights standards can help identify the minimum content of States' benefitsharing obligations, notably in relation to necessary procedural guarantees that tend to remain unspecified in international biodiversity law. This is a significant contribution in limiting State discretion in the choice of means of implementation under the CBD and enhancing justiciability. International biodiversity law, in turn, provides specific guidelines on how to put human rights precepts in practice within the complex landscape of environmental regulation, thereby emphasising the potentially proactive purpose of impact assessments, FPIC and benefit-sharing to support the full realization of indigenous peoples' and local communities' rights, rather than just their protection.

The exploration of the full potential for a mutually supportive interpretation has led to a series of further normative arguments. First, benefit-sharing has both a procedural dimension (communities' agency in the context of a concerned and iterative dialogue aimed at understanding and

\footnotetext{
${ }^{331}$ Ibid, 293.

${ }^{332} \mathrm{C}$ Kamphuis, 'Contesting Indigenous-Industry Agreements in Latin America' in D Newman and I Odumosu-Ayanu (eds), The Law and Politics of Indigenous-Industry Agreements (Routledge, forth 2018).
} 
accommodating different worldviews) and a substantive one (the enhancement of communities' choice and capabilities). To realise the latter, both benefits protecting or enhancing communities' control over natural resources, and benefits providing support for the exercise of effective control are needed. Second, the interplay between benefit-sharing, impact assessment and FPIC highlights opportunities to move away from a technocratic, damage-control approach to natural resource development, by shifting to collaboratively identifying and understanding opportunities for positive impacts according to indigenous peoples' and local communities' worldviews, in addition to potential negative impacts. This calls for re-thinking the scope and methodological approach of existing impact assessments at the national level. In addition, the consideration of alternatives and of the justification of the final outcome need to evidence how assessments differed from merely providing a pre-set of development options to indigenous peoples.

With regard to FPIC, the interplay with benefit-sharing serves to identify circumstances under which indigenous peoples would be legitimately entitled to say "no" to proposed extractive operations or the creation of protected areas affecting traditionally owned or used resources, or having the potential to negatively impact on traditionally used resources threatening the indigenous peoples' cultural and physical survival. Such circumstances include the lack of an early, genuine and cultural appropriate identification and discussion of benefits according to communities' worldviews; or the lack of any impact for communities on the final outcome of benefit-sharing discussions, without sufficient reasons to justify such an outcome. Furthermore, benefit-sharing should be distinguished from compensation, as the latter represents a secondary obligation deriving from and commensurate to a violation of the right to natural resources, whereas benefit-sharing should be seen as part and parcel of the general and permanent obligation that is independent of any violation of their rights and related compensation. These considerations have implications also for business due diligence to respect natural resource-related human rights, and for States' obligations to ensure business due diligence through domestic law-making, enforcement and access to justice, including oversight of contractual and international investment agreements. 
Ultimately, the value and limitations of proposed interpretation on fair and equitable benefitsharing will likely be tested through cross-compliance of international biodiversity law by international human rights processes, ${ }^{333}$ as compliance mechanisms under multilateral environmental agreements are less accessible to non-State actors and have little to offer in terms of redress. ${ }^{334}$ Opportunities for crosscompliance could therefore be more fully explored by scholars and activists alike.

\footnotetext{
${ }^{333}$ Note, however, serious questions with regard to the degree of compliance with their decisions: eg, X Dai, 'The Compliance Gap and the Efficiency of International Human Rights Institutions' in T Risse (ed), The Persistent Power of Human Rights (Cambridge University Press, 2013) 85.

${ }^{334}$ See generally F Francioni, 'Realism, Utopia and the Future of International Environmental Law' in A Cassese (ed), Realizing Utopia: The Future of International Law 443 (Oxford University Press, 2012) 442; and specifically E

Morgera, 'Compliance under Biodiversity-related Conventions: the Case of the Convention on Biological Diversity' in M Lewis, T Honkonen and S Romppanen (eds), International Environmental Law-making and Diplomacy Review 2016 (UNEP, 2017) 133.
} 